\title{
WP/18/102
}

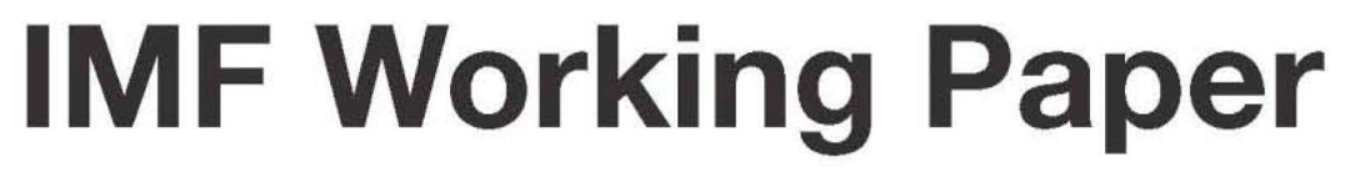

\section{Are Remittances Good for Labor Markets in LICs, MICs and Fragile States? Evidence from Cross-Country Data}

by Ralph Chami, Ekkehard Ernst, Connel Fullenkamp, and Anne Oeking

IMF Working Papers describe research in progress by the author(s) and are published to elicit comments and to encourage debate. The views expressed in IMF Working Papers are those of the author(s) and do not necessarily represent the views of the IMF, its Executive Board, or IMF management.

$$
\text { I N T E R N A T I O N A L M O N E T A R Y F U N D }
$$




\section{WP/18/102}

\section{IMF Working Paper}

\section{Are Remittances Good for Labor Markets in LICs, MICs and Fragile States? Evidence from Cross-Country Data}

by Ralph Chami, Ekkehard Ernst, Connel Fullenkamp, and Anne Oeking

IMF Working Papers describe research in progress by the author(s) and are published to elicit comments and to encourage debate. The views expressed in IMF Working Papers are those of the author(s) and do not necessarily represent the views of the IMF, its Executive Board, or IMF management. 


\title{
IMF Working Paper
}

Institute for Capacity Development

\section{Are Remittances Good for Labor Markets in LICs, MICs and Fragile States? Evidence from Cross-Country Data}

\section{Prepared by Ralph Chami, Ekkehard Ernst, Connel Fullenkamp, and Anne Oeking ${ }^{1}$}

\author{
May 2018
}

\section{IMF Working Papers describe research in progress by the author(s) and are published to elicit comments and to encourage debate. The views expressed in IMF Working Papers are those of the author(s) and do not necessarily represent the views of the IMF, its Executive Board, or IMF management.}

\begin{abstract}
We present cross-country evidence on the impact of remittances on labor market outcomes. Remittances appear to have a strong impact on both labor supply and labor demand in recipient countries. These effects are highly significant and greater in size than those of foreign direct investment or offcial development aid. On the supply side, remittances reduce labor force participation and increase informality of the labor market. In addition, male and female labor supply show significantly different sensitivities to remittances. On the demand side, remittances reduce overall unemployment but benefit mostly lower-wage, lowerproductivity nontradables industries at the expense of high-productivity, high-wage tradables sectors. As a consequence, even though inequality declines as a result of larger remittances, average wage and productivity growth declines, the latter more strongly than the former leading to an increase in the labor income share. In fragile states, in contrast, remittances impose a positive externality, possibly because the tradables sector tends to be underdeveloped. Our findings indicate that reforms to foster inclusive growth need to take into account the role of remittances in order to be successful.
\end{abstract}

JEL Classification Numbers: D33, E24, E26, F24, J21, J23

Keywords: Remittances, fragile countries, low income countries, middle income countries, Dutch Disease, labor markets, inclusive growth

Author’s E-Mail: rchami@imf.org, ernste@ilo.org, cfullenk@duke.edu, aoeking@imf.org

\footnotetext{
${ }^{1}$ The authors thank colleagues in the African Department, Middle East and Central Asia Department, Research Department, Strategy Policy and Review Department, and Western Hemisphere Department of the IMF, as well as at the International Labour Organization, for helpful comments and suggestions. Part of the research for this work was carried out while Ekkehard Ernst was visiting scholar at the IMF Institute for Capacity Development (ICD); he would like to thank ICD and colleagues there for the generous support received.
}

This paper was supported in part through a research project on macroeconomic policy in low-income and developing countries with the UK's Department for International Development. The views expressed in this paper are those of the authors and should not be reported as representing the views of the IMF or DFID. 


\section{Contents}

1 Introduction $\underline{4}$

2 Literature review $\underline{6}$

3 Empirical assessment $\quad \underline{10}$

3.1 Data and methodology ................. 10

3.2 Labor demand: Unemployment and remittances . . . . . . . . 12

3.3 Labor supply: Labor force participation and remittances . . . . . . 14

3.4 Wages and inequality .................. 18

3.4.1 Do remittances lift wages? ............... 18

3.4.2 Remittances and the labor income share ........ 20

3.4.3 How does inequality evolve? ............ . 21

3.4.4 Do remittances increase informality? . . . . . . . . 22

3.5 Sectoral shifts . . . . . . . . . . . . . . . 24

3.6 Regional variation . . . . . . . . . . . . . $\underline{27}$

3.7 Remittances in fragile states . . . . . . . . . . . $\underline{30}$

4 Conclusion $\quad \underline{33}$

5 Appendix $\quad \underline{40}$

5.1 Summary statistics ................... 40

5.2 Regional country coverage . . . . . . . . . . . . . 41

\section{List of Tables}

1 Unemployment dynamics and income flows . . . . . . . . . 14

2 Dependent variable: Labor force participation rate . . . . . . $\underline{15}$

3 Dependent variable: Male labor force participation rate . . . . . $\underline{16}$

4 Dependent variable: Female labor force participation rate . . . . . 17

5 Wage growth and remittances ............. 20 
6 Change in the labor income share and remittances . . . . . . . 21

7 Determinants of market inequality . . . . . . . . . 22

8 Remittances and informal employment ............ 23

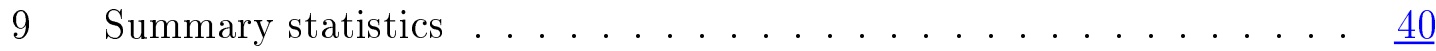

10 Regional country coverage .................... 41

\section{List of Figures}

1 Labor force participation rates - Quantile regressions . . . . . $\underline{18}$

2 Sectoral employment impact of remittances . . . . . . . . $\underline{25}$

3 Sectoral employment - Quantile regressions . . . . . . . . $\underline{26}$

4 Remittances and labor force participation by region ........ $\underline{28}$

5 Remittances and informal employment by region . . . . . . . . $\underline{29}$

6 Remittances and wages by region ............. 30

$7 \quad$ Impact of remittances on labor force participation rates . . . . . . $\underline{31}$

8 The impact of remittances on wage growth and inequality . . . . $\underline{32}$

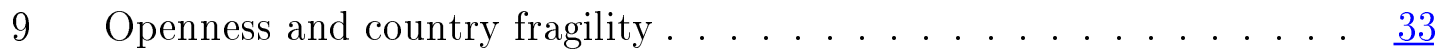




\section{Introduction}

By now, it is well known that immigrant remittances are one of the largest types of international financial flows, amounting to over $\$ 400$ billion in the year 2015 , and second only to foreign direct investment in terms of size. In addition, for many developing countries, remittances are quite large relative to GDP. During 2015, around 30 countries received remittance transfers worth more than five percent of GDP, and many more countries received remittances worth more than one percent of GDP.

Financial flows of this magnitude can be expected to have multiple significant impacts on the economies of remittance-receiving countries. For example, much attention has been paid to the goods market consequences of remittance receipt, such as the potential "Dutch disease" effects of remittances(Acosta et al., 2009; Barajas et al., 2011). Likewise, there are good reasons to expect that remittance inflows would have important consequences for a country's labor market. First, remittances constitute an important source of income for millions of families around the world, lifting many of them out of poverty. To the extent that remittance receipt affects households' consumption and investment decisions, there may be significant follow-on effects of these decisions on labor demand.

At the same time, remittances are also a non-market income transfer, and as such, can have significant impacts on the labor supply behavior of members of remittancereceiving households. Remittances are an alternative to labor income, and may therefore affect labor force participation, reservation wages, and occupational choice, among other labor supply outcomes. In addition, since households' investment opportunities include education and training, remittances may also affect labor supply through this channel.

Because of the size of remittance flows, and the many ways that they can affect the labor market, remittance-receiving countries may exhibit wage and employment dynamics that are quite different from those in countries for which remittance receipt is trivial (or negative, as in remittance-sending countries). These differences have important implications for policymakers in remittance-receiving countries who are trying to understand trends in their labor statistics or to design policies to increase employment or improve employment opportunities for their citizens.

In addition, labor market outcomes are an important determinant of long-run growth. The quantity and quality of labor in an economy - the human capital - help determine potential GDP as well as the growth rate of actual GDP. Much research has been devoted to investigating the impact of remittance receipt on economic growth, and the findings have presented a bit of a puzzle, in the sense that remittances do not appear to increase economic growth and may in fact hinder it. Part of the explanation for these results may be found in the labor market consequences of remittances. For example, Chami et al. (2003) argue that remittances reduce work incentives and therefore decrease labor supply and economic growth.

Thus, there are many reasons why systematic and comprehensive study of the 
labor market effects of remittance receipt would be useful and interesting. This paper conducts a cross-country study of the labor-market effects of remittance receipt that contributes to the literature in four ways. First, nearly all previous studies of the labor market effects of migration and remittances examine a single labor market outcome, such as labor force participation, in a single-country context, using household-level data. ${ }^{1}$ We examine the impact of remittances on unemployment, labor force participation, wage growth, and inequality across many countries, using aggregate data. In addition to estimating average effects across all countries, we also measure the variation in these effects across geographic regions, country income levels, and degree of fragility.

The second contribution of this research is that we estimate the effects of remittance receipt on sectoral employment in 14 different sectors. This exercise sheds additional light on the labor market impacts of remittances and suggests a consistent interpretation of our findings.

The third contribution of the paper regards data. This paper uses data from the ILO Global Wage Database, as well as from the ILO Global Employment Trends and Sectoral Employment databases. The latter datasets have not been used in connection with remittances before.

Finally, the paper also provides robust evidence in support of both existing and new stylized facts regarding the impact of remittances on labor markets. To begin with, we find consistently strong evidence that remittances have significant negative impacts on labor supply and positive effects on labor demand. Remittances reduce labor force participation and increase labor market informality, but also reduce unemployment. We also find, moreover, that these effects are consistently larger and more statistically significant than the effects of foreign direct investment (FDI) or official development assistance (ODA) on labor markets.

We also find strong evidence that remittances have differential effects across labor market segments such as males and females, and across industrial sectors. This evidence helps reconcile some of our findings from the aggregate data, particularly that remittances reduce both wage growth and inequality. For example, we find that remittances increase employment in the construction and real-estate sectors but reduce employment in manufacturing. This evidence in turn suggests that composition effects are important to understanding how remittances affect labor markets.

In addition, we find evidence of regional variation in labor-market impacts of remittances. For example, the impact of remittances on labor market informality is greater in regions where informality is lower. This is also one of the first papers to examine whether remittances have different effects in fragile states versus more stable states. We find that remittances actually increase wage growth and do not depress labor force participation in fragile states, which are the opposite of the effects

\footnotetext{
${ }^{1}$ See, for example, Binzel and Assaad (2011); Dustmann et al. (2015); Elsner (2013a); Funkhouser (1992); Grigorian and Melkonyan (2011); Hanson (2007); Kim (2007); Lokshin and Glinskaya (2009) and Rodriguez and Tiongson (2001).
} 
found both on average and for more stable states.

We argue that all the labor-market effects of remittances we document in this paper tell a remarkably consistent story. For example, our findings are consistent with a Dutch Disease narrative in which remittance inflows change the relative prices of tradables, which are produced using more productive labor, and nontradables, which are produced using less productive labor, to favor nontradables at the expense of tradables. In this case, employment falls in the tradable sector but rises in the nontradable sector. These effects are consistent with a fall in overall unemployment, if employment in the nontradable sector with less-productive labor rises by more than employment in the tradable sector declines. But this outcome is also consistent with a lower rate of wage growth and a fall in measured inequality, due to the change in the composition of the employed.

This story in turn provides a deeper explanation of why previous work has found that remittances generally fail to boost economic growth in recipient economies. Remittances not only appear to decrease labor supply across the board, but they also benefit some segments of the labor market, and the overall economy, at the expense of others. The mixed effects offset each other and imply a negligible net impact on economic growth.

The evidence we present in this paper reinforces two broad messages that have emerged from the literature on the macroeconomic consequences of remittances. ${ }^{2}$ First, the effects of remittances on the receiving economies are complex because of multiple pathways through which remittances affect recipients' behavior. Second, remittances do not appear to be an unmitigated boon for any recipient economy. In particular, we find that they can have serious negative consequences for labor market outcomes, including for workers who do not receive these transfers. Therefore, countries that receive significant remittance flows need to integrate strategies for dealing with remittances into their overall development plans. We detail some suggestions for doing so in the conclusion.

The rest of the paper is organized as follows. Section 2 reviews the literature on the labor market effects of both migration and remittances. Section 3 presents the data and estimation strategies used in the paper, and presents the results. Section 4 presents an overall interpretation of the empirical results, and Section 5 concludes.

\section{Literature review}

When considering the impact of remittances on labor-market outcomes, it is important to take the literature on emigration and labor markets into account as well. ${ }^{3}$ Many papers in the emigration literature complement the findings in the remittances

\footnotetext{
${ }^{2}$ See, for example, Chami et al. (2008)

${ }^{3}$ See Antman (2013) for a review of the literature that includes the effects of both remittances and emigration on various labor market outcomes.
} 
literature, while other papers on emigration utilize a "remittance channel" to explain why emigration affects labor market outcomes. In addition, emigration may affect some labor market outcomes differently than remittances do, although these effects may be difficult to disentangle empirically. ${ }^{4}$ We organize our review of the literature on labor market impacts of remittances and emigration by the type of labor market outcome affected by these activities. We begin with wages, because the findings in this literature can help frame, and shed light on, some of the findings regarding other labor-market impacts.

Emigration may have a significant impact on wages in the labor-sending country. Many studies -- recently Elsner (2013a) for Lithuania, Elsner (2013b) for the postSoviet era, and Dustmann et al. (2015) for Poland -- find that emigration increases wages, because it reduces the size of the labor force. Mishra (2014) gives an extensive survey of this literature. It is important to note that these studies use household-level survey data to estimate the impacts of migration on wages. Docquier et al. (2013) examine the wage impacts of emigration in OECD countries, using a simulation model calibrated with parameter estimates taken from the empirical literature. This paper finds that emigration decreases the supply of highly educated workers and therefore increases their wages. And because their model includes a positive externality in which highly educated workers raise total factor productivity, emigration reduces the wages of low-skilled workers since it is mostly the highly educated who migrate.

A related paper that directly considers labor productivity is $\mathrm{Al}$ Mamun et al. (2015). This research finds a positive impact of remittances on labor productivity, in countries that both receive large amounts of remittances and have large labor forces. This effect does seem to decline as the amount of remittances increases above some threshold, however, and in fact the paper also finds that there is an insignificant effect of remittances on labor productivity in countries with very high remittance-GDP ratios. Although the authors propose several explanations for their findings, these results are also consistent with the findings regarding the impact of emigration on wages. Since remittances are correlated with migration, the increase in remittances can also coincide with a decline in the labor force, which increases labor productivity as firms move along the labor-demand curve and wages increase in response to the fall in labor supply.

Another labor-market issue related to the labor-supply effects of emigration is the so-called brain drain that affects many developing countries (Docquier et al., 2013). This phrase describes the fact that for many developing countries, highly skilled emigrants outnumber low-skilled emigrants. This phenomenon affects the markets for these skilled workers and potentially creates shortages of highly skilled labor, such as physician labor. In addition, governments may react to the outflow of skilled labor by adjusting the subsidies to education.

Much of the literature on the labor-market impact of emigration and remittances

\footnotetext{
${ }^{4}$ Hanson (2007), for example, discusses some ways that emigration and remittances may have different effects on labor market outcomes.
} 
focuses on labor-market participation. Many papers find that the labor force participation of family members who remain in the labor-sending country decreases when members emigrate or send remittances. One of the earliest papers in this literature is Funkhouser (1992), who found that remittances reduced labor force participation in Managua, Nicaragua. Other papers, including Airola (2008), Hanson (2007), Kim (2007), and Acosta et al. (2008) support these findings for different countries in Latin America. Studies performed on countries outside Latin America come to similar Conclusions, such as Kozel and Alderman (1990) for Pakistan, Rodriguez and Tiongson (2001) in the Philippines. Lokshin and Glinskaya (2009) for Nepal, or Grigorian and Melkonyan (2011) in Armenia. Abdulloev et al. (2014) find that there is a negative effect of emigration on the labor force participation among men in Tajikistan that is separate from the effect of remittances.

One study that contradicts the above findings is Posso (2012). This author examines the behavior of aggregate labor supply rather than the behavior of individuals, and performs a cross-country analysis using a 25-year panel. This paper finds that remittances increase the aggregate labor force participation of men, including those who do not receive remittances. The author argues that the increase in labor force participation is the result of non-migrant households who want to migrate after watching neighboring households receive remittances from members who emigrated, and therefore join the labor force in order to accumulate the skills and experience required to find employment abroad. This idea of a demonstration effect in migration and remittance receipt that changes the behavior of non-migrant households (that is, households with no members who emigrated) is a recurrent theme in this literature. On the other hand, given the findings discussed above that emigration increases wages in the labor-sending country, this result could simply reflect an increase in wages above many people's reservation wage. To the extent that remittances raise their recipients' reservation wages, it is possible that remittances may simultaneously decrease labor force participation of some households' members but increase overall labor force participation.

Relatively few studies have considered the impact of emigration or remittances on the level of unemployment, but the ones that have typically utilize aggregate, cross-country data and hence give a perspective that differs from that of individual country studies that use household-level data. Drinkwater et al. (2009) failed to find a significant effect of remittances on unemployment across countries, but Jackmann (2014) found a positive and significant impact of remittances on unemployment for countries in Latin American and the Caribbean that have low remittance-GDP ratios. But the estimations in this paper also allowed the remittances-unemployment relationship to be nonlinear, through the use of a threshold effect, and for countries with high remittance-GDP ratios, it was found that remittances have a negative impact on unemployment.

An issue that is related to labor force participation is occupational choice. Emigration and remittances appear to have significant effects on the broad types of work that people choose to do, such as formal and informal employment, self-employment, 
and unpaid work such as caring for family members or contributing labor on a family farm. For example, Amuedo-Dorantes and Pozo (2006a) find that remittances reduce the amount of hours that men spend in formal work and self-employment, and increase the amount of hours spent in informal work. Similarly, Binzel and Assaad (2011) find that remittances reduce the amount of paid work outside the home that women perform in Egypt. Görlich et al. (2007) also find that remittances cause women in Moldova to decrease paid work in favor of unpaid household work. Cabegin (2006) finds that migration lowers female labor force participation and increases household work. More recently, Ivlevs (2016) finds that remittances and emigration increases the share of informal employment in a sample of six transition economies, using the Social Exclusion Survey conducted in Kazakhstan, the FYR Macedonia, Moldova, Serbia, Tajikistan and Ukraine in 2009.

The remittances literature has also focused on the choice to become self-employed. Amuedo-Dorantes and Pozo (2006b) find that remittance receipt lowers the likelihood of business ownership in the Dominican Republic, and Demirgüç-Kunt et al. (2011) obtain a similar result for Bosnia and Herzegovina. Other studies, however, find that remittances increase the likelihood of self-employment, including Funkhouser (1992) and Stanley (2015). Edwards and Rodríguez-Oreggia (2009) find that remittances increase labor force participation for some women in Mexico, and argue that this effect may be due to self-employment. The conflicting results in the literature reflect the uncertain theoretical relationship between remittances and self-employment. Remittances may loosen the financing constraints preventing people from becoming self-employed, or they may lessen the necessity of becoming self-employed in situations where employment opportunities are limited.

Remittances may not only affect the choice of work, but also the amount of effort expended on the job. This is difficult to measure for regular employment, but some studies that focus on agriculture find evidence that remittances change the effort that farmers put forth. For example, Khanal et al. (2015) find that remittance receipt among rural families in Nepal increases the amount of land that farmers abandon (that is, the amount of land left permanently fallow). Damon (2010) finds that remittance receipt increases the amount of land that farmers devote to subsistence crops and reduces the amount devoted to cash crops.

The impact of emigration and remittances on educational choices has also been studied. Several papers find that remittance receipt reduces child wage labor and increases recipient spending on education. These include Edwards and Ureta (2003), Yang (2008), Calero et al. (2009), Acosta (2011), and Alcaraz et al. (2012). Older students may be influenced by the "brain gain" phenomenon, in which the migration of highly skilled workers may give young people the incentive to obtain more education, so that they too will have the opportunity to migrate. This is yet another example of the demonstration effect of migration and remittance receipt that may have a significant impact on individuals' labor-market behavior. Although there are some documented cases in which the "brain gain" motivation may be evident, most research suggests that this benefit is outweighed by other economic and social losses 
due to brain drain, which go beyond the labor-market impacts.

Overall, the evidence from the existing literature tells a remarkably consistent story about the aggregate labor-market effects of remittances. Wages and productivity tend to increase as a result of emigration and remittances, which appears to be consistent with a decrease in overall labor supply due to emigration. In addition, remittances decrease labor-force participation among recipients, which (ceteris paribus) also tends to reduce labor supply and contribute to increased wages. Remittances also tend to induce people to shift away from formal employment and toward informal and unpaid work, reducing the supply of labor in the market for formal employment, again placing upward pressure on wages. An interesting question, however, is whether remittances reduce aggregate labor force participation or, as the evidence from Posso (2012) suggests, increase it. The evidence regarding the effect of emigration and remittances on self-employment, entrepreneurship, and on the unemployment rate, on the other hand, is mixed. And while remittances appear to reduce child labor and increase educational spending, these effects probably do not have any effect on the labor market for adult workers.

Given the limited amount of research in this area that utilizes aggregate data and cross-country analysis, one important question is whether the findings from the previous literature are confirmed or contradicted by the aggregate data, and whether the aggregated data produces a set of stylized facts that is also internally consistent across different labor market outcomes. We therefore turn next to empirical exercises that aim to answer these questions.

\section{$3 \quad$ Empirical assessment}

As discussed in the introduction, our goal is to compile a broad set of stylized facts regarding the labor market effects of remittances in the hope that they would suggest a consistent theoretical framework for interpreting their role in the labor market and overall economy. We estimate the effects of remittances on the following measures of labor market performance: labor demand, as captured by unemployment; labor supply, as measured by labor force participation; wages, inequality, and finally, sectoral shifts in employment.

\subsection{Data and methodology}

Data. Remittances data is taken from the category "Personal Transfers" in the IMF Balance of Payments Statistics and refers to current transfers by non-resident households to resident households. This is a narrower remittance definition than sometimes used in the literature, but captures our definition of remittances: regular and unrequited private transfers from residents in one country to another. ${ }^{5}$

\footnotetext{
${ }^{5}$ For a discussion of the measurement of remittances, see Chami et al. (2008)
} 
Foreign direct investment data is sourced from the IMF Balance of Payments Statistics and official development assistance data from the OECD International Development Statistics database.

Employment data are taken from the ILO Global Employment Trends data-base that covers labor market information for 177 countries between 1991 and 2015. The database contains information on labor force participation, unemployment, employment, sectoral employment and self employment. The database is a balanced panel with approximately half of the observations being imputed using statistical estimates based on Okun's law relations between employment and GDP growth. ${ }^{6}$ Estimations have been carried out using both the full database (i.e. real and imputed values) as well as only real observations.

The wage data comes from the ILO Global Wage Database augmented by information provided by the ILO Wage Projection database (see ILO Global Wage Database and Ernst et al., 2016). The data covers a panel of 112 countries for a period of nearly 20 years (1995 to 2014). In order to keep consistency across different countries, wage series have been chosen such that they cover a wide range of sectors and regions within a country, and therefore are representative of the labor market as a whole.

Gini coefficients are used to measure changes in income inequality and are taken from the Standardized World Income Inequality Database (SWIID).The SWIID currently incorporates comparable Gini indices of net and market income inequality for 174 countries for as many years as possible from 1960 to the present; it also includes information on absolute and relative redistribution. For our purposes, we have concentrated on market income inequality in order to avoid estimation biases arising from cross-country differences in redistribution efforts. Most countries that receive significant amounts of remittances have - at best - only relatively under-developed social security systems or none at all, with the exception of some Central Asian economies that have inherited relatively well-developed (pension) security systems from the past. In order to ensure that institutional specificities mostly found in advanced economies are not biasing our results, we also present estimates on the smaller sample containing only non-OECD countries.

Summary statistics of the main variables used in the empirical work can be found in the Appendix in Table 9.

Methodology. Labor market indicators are typically slowly moving variables that exhibit high levels of persistence at the annual frequency. As a consequence, wherever possible, dynamic adjustment models were used to control for such persistence. In particular, labor market dynamics related to labor force participation, (un-)employment, wages and income inequality have been estimated as dynamic adjustment processes. Only in the case of sectoral employment did the overidentifi-

\footnotetext{
${ }^{6}$ See ILO Trends Econometric Models for more details on the imputation methodology.
} 
cation restrictions preclude a proper dynamic treatment. In particular, the following equation has been estimated:

$$
Y_{i t}=\beta \cdot Y_{i t-1}+\gamma \cdot \text { Remittances }_{i t}+\delta \cdot \boldsymbol{X}_{i t}+\varepsilon_{i t}
$$

where $Y_{i t}$ : the relevant labor market indicator, Remittances ${ }_{i t}$ : remittances as a share of GDP and $\boldsymbol{X}_{i t}$ : a vector of control variables. Control variables vary, depending on the dependent variable, but include the level of development, GDP growth, investment share of GDP, and demographic variables such as the share of working-age population. When wages were used as dependent variables, both wage curves and wage inflation curves have been estimated, adding unemployment to the independent variables.

A panel-VAR estimation approach was not feasible, due to the fact that our panel is unbalanced as well the fact that most labor market variables for low-income countries are available only for few years. Instead, we opted for the Arellano-Bond (system) GMM estimator that uses lagged instances of the dependent variable to address endogeneity issues. Using the Sargan test to identify the lag structure (typically, the shortest possible lag has been chosen for the dependent variable) helped to limit the number of instruments. Indeed, ensuring that the overidentifying restrictions are valid typically led to only a small number of instruments (reported in the regression tables), in comparison to the degrees of freedom. Given the global sample of our database, typically the number of countries in each regression exceeds the number of years per country by a factor of five or more, justifying the use of GMM (instead of alternative estimators to deal with lagged dependent variables). Moreover, the version of the GMM estimator used here allows the presence of low-level auto-correlation in the error term, which is what we would expect in our database. ${ }^{7}$

Only in the case of sectoral employment shares did dynamic adjustment models prove infeasible to be estimated, as the overidentification restrictions were never valid for significant lagged dependent variables. Instead, for sectoral employment shares $\beta=0$ has been assumed in equation (1) and the equation has been estimated using standard fixed-effects OLS.

In addition, quantile regressions have been carried out in order to better understand at what level of the conditional distribution the effects of remittances on the different labor market indicators are most prominent. For ease of comparison, the results of these regressions are being reported only graphically but do include confidence intervals around the central estimates.

\subsection{Labor demand: Unemployment and remittances}

Measuring labor demand in most low- and middle-income countries is complicated by the fact that informal employment is widespread and hides the true amount of

\footnotetext{
${ }^{7}$ Formal tests should confirm, indeed, the presence of $\mathrm{AR}(1)$ autocorrelation in the error terms; detailed results available from the authors upon request.
} 
under-employment. ${ }^{8}$ In the absence of more precise and widely available indicators of labor demand, we chose to use ILO's global unemployment estimates as a proxy, but also checked our results by re-running the estimations using only real observations.

In Table 1, we report the results of a dynamic Okun's curve specification, augmented with various capital and income flows. In addition, we report results limiting our sample to only non-OECD countries in order to control for a possible upward bias of elasticities due to a higher reactivity of unemployment to labor demand in more advanced economies. ${ }^{9}$ In order to account for differences in unemployment rates linked to differences in the level of economic development, we also control for GDP per capita.

Results reported in Table 1 demonstrate that unemployment declines significantly and strongly across all specifications with a rise in the share of remittances, be they contemporaneous or lagged (see specification (2)). The estimated coefficient seems indeed to be smaller when the sample is limited only to non-OECD countries (around $1 / 3$ smaller, see specification (6)), suggesting that, indeed, unemployment is less well suited to account for changes in labor demand in low-income and emerging countries with large informal labor markets. Interestingly, when limiting the sample only to real observations (specification (7)), the estimated coefficient is almost twice as large as in the other specifications, suggesting that -if anything - our results underestimate the true effect of remittances on labor demand when using a larger database that includes a significant amount of imputed data points. Also, as mentioned above, remittances have both a larger and more consistently significant impact on unemployment than either FDI or ODA, when all three are included in the estimations.

\footnotetext{
${ }^{8}$ See ILO (2015) for a discussion of labor demand, employment and under-employment in the context of weakly institutionalized and emerging countries.

${ }^{9}$ For a discussion of changes in estimated Okun's coefficients depending on the level of development, see Ball et al. (2013); Cazes et al. (2013).
} 
Table 1: Unemployment dynamics and income flows

\begin{tabular}{|c|c|c|c|c|c|c|c|c|}
\hline & $\begin{array}{c}(1) \\
\text { Baseline }\end{array}$ & $\begin{array}{c}(2) \\
\text { Investment }\end{array}$ & $\begin{array}{c}(3) \\
\text { All income } \\
\text { flows }\end{array}$ & $\begin{array}{c}\text { (4) } \\
+ \text { GDP per capita }\end{array}$ & $\begin{array}{c}(5) \\
\text { +GDP per capita } \\
\text { Non-OECD countries }\end{array}$ & $\begin{array}{c}6) \\
\text { Baseline: } \\
\text { Non-OECD countries }\end{array}$ & $\begin{array}{c}(7) \\
\text { Baseline: } \\
\text { real observations }\end{array}$ & $\begin{array}{c}(8) \\
\text { Investment: } \\
\text { real observations }\end{array}$ \\
\hline $\begin{array}{l}\text { Unemployment } \\
\text { (lagged) }\end{array}$ & $\begin{array}{c}0.503^{* * *} \\
(0.137)\end{array}$ & $\begin{array}{l}0.404^{* * *} \\
(0.0397)\end{array}$ & $\begin{array}{l}0.426^{* * *} \\
(0.0474)\end{array}$ & $\begin{array}{c}0.420^{* * * *} \\
(0.118)\end{array}$ & $\begin{array}{r}0.494^{* * *} \\
(0.0559)\end{array}$ & $\begin{array}{c}0.464^{* * *} \\
(0.136)\end{array}$ & $\begin{array}{r}0.306^{* * *} \\
(0.0660)\end{array}$ & $\begin{array}{c}0.242^{* * *} \\
(0.0554)\end{array}$ \\
\hline GDP growth & $\begin{array}{c}-0.0451^{* * *} \\
(0.0170)\end{array}$ & & $\begin{array}{c}-0.0264^{* * *} \\
(0.00915)\end{array}$ & $\begin{array}{c}-0.0263^{* *} \\
(0.0125)\end{array}$ & $\begin{array}{c}-0.0238^{* *} \\
(0.0116)\end{array}$ & $\begin{array}{c}-0.0295^{*} \\
(0.0171)\end{array}$ & $\begin{array}{c}-0.118^{* * *} \\
(0.0201)\end{array}$ & \\
\hline $\begin{array}{l}\text { Remittances share } \\
\text { (in \% of GDP) }\end{array}$ & $\begin{array}{c}-4.114^{* *} \\
(1.818)\end{array}$ & & $\begin{array}{c}-4.375^{* * *} \\
(1.657)\end{array}$ & $\begin{array}{c}-6.695^{* *} \\
(2.773)\end{array}$ & $\begin{array}{c}-6.954^{* * *} \\
(2.554)\end{array}$ & $\begin{array}{c}-4.234^{* *} \\
(1.877)\end{array}$ & $\begin{array}{c}-11.62^{* *} \\
(5.278)\end{array}$ & $\begin{array}{c}-6.866^{* *} \\
(2.769)\end{array}$ \\
\hline $\begin{array}{l}\text { Investment share } \\
\text { (in \% of GDP) }\end{array}$ & & $\begin{array}{c}-0.133^{* * *} \\
(0.0224)\end{array}$ & & & & & & $\begin{array}{c}-0.171^{* * *} \\
(0.0304)\end{array}$ \\
\hline $\begin{array}{l}\text { Remittances share } \\
\text { (lagged, in \% of GDP) }\end{array}$ & & $\begin{array}{c}-5.355^{* *} \\
(2.666)\end{array}$ & & & & & & \\
\hline $\begin{array}{l}\text { FDI share } \\
\text { (in \% of GDP) }\end{array}$ & & & $\begin{array}{l}-1.233 \\
(0.901)\end{array}$ & $\begin{array}{l}-0.791 \\
(2.396)\end{array}$ & $\begin{array}{l}-0.764 \\
(1.104)\end{array}$ & & & \\
\hline $\begin{array}{l}\text { Official aid share } \\
\text { (lagged, in \% of GDP) }\end{array}$ & & & $\begin{array}{c}0.00645 \\
(0.00806)\end{array}$ & $\begin{array}{l}-0.00976 \\
(0.00960)\end{array}$ & $\begin{array}{c}-0.0136 \\
(0.00949)\end{array}$ & & & \\
\hline GDP per capita & & & & $\begin{array}{l}-2.23 \mathrm{e}-05 \\
(6.71 \mathrm{e}-05)\end{array}$ & $\begin{array}{c}4.10 \mathrm{e}-05 \\
(5.22 \mathrm{e}-05)\end{array}$ & & & \\
\hline Constant & $\begin{array}{c}4.632^{* * *} \\
(1.252) \\
\end{array}$ & $\begin{array}{c}8.620^{* * *} \\
(0.692)\end{array}$ & $\begin{array}{c}5.833^{* * *} \\
(0.586) \\
\end{array}$ & $\begin{array}{c}6.174^{* * *} \\
(1.410) \\
\end{array}$ & $\begin{array}{c}5.327^{* * *} \\
(0.735) \\
\end{array}$ & $\begin{array}{c}5.039^{* * *} \\
(1.303) \\
\end{array}$ & $\begin{array}{c}7.183^{* * *} \\
(0.633) \\
\end{array}$ & $\begin{array}{c}10.12^{* * *} \\
(0.786)\end{array}$ \\
\hline Observations & 2,284 & 2,153 & 1,826 & 1,804 & 1,725 & 1,929 & 1,361 & 1,331 \\
\hline Number of countries & 139 & 132 & 120 & 120 & 115 & 117 & 124 & 118 \\
\hline Number of instruments & 69 & 69 & 143 & 131 & 132 & 132 & 119 & 65 \\
\hline
\end{tabular}

Note: Dynamic estimates using Arellano-Bond system GMM estimator, two-step estimator with robust errors. Equations 5 and 6 limit the sample to actually observed data points. Standard errors in parentheses. ${ }^{* * *} \mathrm{p}<0.01,{ }^{* *} \mathrm{p}<0.05,{ }^{*} \mathrm{p}<0.1$.

The above results can be consistent both with a fall in labor force participation and with an increase in labor demand. For example, if labor force participation falls among the unemployed by a greater proportion than among the total labor force (because of discouragement, for instance), such a fall in the participation rate could, by itself, cause total employment to decline despite a fall in the unemployment rate. Therefore, we must also examine the supply effect of remittances to get a better understanding of their effects on total labor demand, which is the purpose of the next sub-section.

\subsection{Labor supply: Labor force participation and remittances}

We first look at the impact of remittances on labor supply, as measured by the labor force participation rate (see Table 2). In the absence of good measures of standard control variables for labor force dynamics, only a lagged dependent variable and the size of the working-age population has been used..$^{10}$ As the table demonstrates, remittances enter negatively and robustly across different specifications, including when the sample is limited to non-OECD countries (see specification (6)). Also, additional controls such as time dummies, investment ratios, the GDP per capita level relative to the United States, trade openness or real wages (either growth or

\footnotetext{
${ }^{10}$ Typical control variables to estimate aggregate labor supply equations would include the wage rate, the level of taxation and alternative income sources from social protection. In the country sample that we are using in this paper, none of this information is available for the large majority of countries (see Burniaux et al., 2003; Ernst and Rani, 2011 for typical labor supply estimations).
} 
levels) do not change the negative sign of remittances on labor force participation rates. In contrast to remittances, however, official aid enters positively, suggesting that the unconditional nature of remittances generates a strong income effect that depresses labor supply. FDI, on the other hand, does not seem to affect labor force participation in most specifications.

Table 2: Dependent variable: Labor force participation rate

\begin{tabular}{|c|c|c|c|c|c|c|c|c|c|}
\hline Controls & $\begin{array}{c}(1) \\
\text { Remittances }\end{array}$ & $\begin{array}{c}(2) \\
\text { Working-age } \\
\text { population }\end{array}$ & $\begin{array}{c}(3) \\
\text { All income } \\
\text { flows }\end{array}$ & $\begin{array}{c}(4) \\
+ \text { Liquid } \\
\text { liabilities }\end{array}$ & $\begin{array}{c}(5) \\
\text { All income } \\
\text { flows }\end{array}$ & $\begin{array}{c}(6) \\
\text { All income flows } \\
\text { Non-OECD countries }\end{array}$ & $\begin{array}{c}(7) \\
\text { All controls: } \\
\text { Wage growth }\end{array}$ & $\begin{array}{c}(8) \\
\text { All controls: } \\
\text { Wage levels }\end{array}$ & $\begin{array}{c}(9) \\
\text { All controls: } \\
\text { Trade openness }\end{array}$ \\
\hline $\begin{array}{l}\text { Labor force participation } \\
\text { rate (lagged) }\end{array}$ & $\begin{array}{l}0.737^{* * *} \\
(0.0961)\end{array}$ & $\begin{array}{l}0.789^{* * *} \\
(0.0628)\end{array}$ & $\begin{array}{l}0.892^{* * *} \\
(0.0474)\end{array}$ & $\begin{array}{c}0.900^{* * *} \\
(0.0476)\end{array}$ & $\begin{array}{l}0.926^{* * *} \\
(0.0347)\end{array}$ & $\begin{array}{l}0.934^{* * *} \\
(0.0346)\end{array}$ & $\begin{array}{l}0.801^{* * *} \\
(0.0585)\end{array}$ & $\begin{array}{l}0.776^{* * *} \\
(0.0589)\end{array}$ & $\begin{array}{l}0.855^{* * *} \\
(0.0444)\end{array}$ \\
\hline $\begin{array}{l}\text { Working-age population } \\
\text { (in \% of total population) }\end{array}$ & & $\begin{array}{l}0.00198^{*} \\
(0.00119)\end{array}$ & $\begin{array}{l}0.00340^{*} \\
(0.00178)\end{array}$ & $\begin{array}{c}0.00232 \\
(0.00232)\end{array}$ & $\begin{array}{l}0.00276^{*} \\
(0.00151)\end{array}$ & $\begin{array}{l}0.00274^{*} \\
(0.00157)\end{array}$ & $\begin{array}{c}-0.00429^{* * *} \\
(0.00160)\end{array}$ & $\begin{array}{c}0.00171 \\
(0.00215)\end{array}$ & $\begin{array}{l}-0.00165 \\
(0.00164)\end{array}$ \\
\hline $\begin{array}{l}\text { Remittances } \\
\text { (as a share of GDP) }\end{array}$ & $\begin{array}{c}-6.220^{* * *} \\
(2.171)\end{array}$ & $\begin{array}{c}-4.302^{* * *} \\
(1.374)\end{array}$ & $\begin{array}{c}-3.191^{* *} \\
(1.429)\end{array}$ & $\begin{array}{c}-2.678^{* *} \\
(1.350)\end{array}$ & $\begin{array}{c}-2.358^{* *} \\
(1.085)\end{array}$ & $\begin{array}{c}-2.292^{* *} \\
(1.164)\end{array}$ & $\begin{array}{c}-6.221^{* * *} \\
(1.393)\end{array}$ & $\begin{array}{c}-7.055^{* * *} \\
(1.792)\end{array}$ & $\begin{array}{c}-3.817^{* * *} \\
(1.232)\end{array}$ \\
\hline $\begin{array}{l}\text { Official aid } \\
\text { (as a share of GDP) }\end{array}$ & & & $\begin{array}{c}0.0426^{* * *} \\
(0.0153)\end{array}$ & $\begin{array}{c}0.0296^{* *} \\
(0.0148)\end{array}$ & $\begin{array}{c}0.0314^{* *} \\
(0.0130)\end{array}$ & $\begin{array}{l}0.0276^{* *} \\
(0.0127)\end{array}$ & & & \\
\hline $\begin{array}{l}\text { FDI } \\
\text { (as a share of GDP) }\end{array}$ & & & $\begin{array}{l}-1.061^{*} \\
(0.608)\end{array}$ & $\begin{array}{l}-0.576 \\
(0.754)\end{array}$ & $\begin{array}{l}-0.902 \\
(0.566)\end{array}$ & $\begin{array}{l}-0.926 \\
(0.606)\end{array}$ & & & \\
\hline $\begin{array}{l}\text { Liquid liabilities } \\
\text { (as a share of GDP) }\end{array}$ & & & & $\begin{array}{c}-0.00951^{* *} \\
(0.00376)\end{array}$ & & & & & \\
\hline $\begin{array}{l}\text { Total investment } \\
\text { (as a share of GDP) }\end{array}$ & & & & & & & $\begin{array}{l}0.0106^{* *} \\
(0.00415)\end{array}$ & $\begin{array}{l}-0.00377 \\
(0.00459)\end{array}$ & $\begin{array}{l}0.00976^{* *} \\
(0.00446)\end{array}$ \\
\hline Real wage growth & & & & & & & $\begin{array}{c}0.0107^{* * *} \\
(0.00338)\end{array}$ & & $\begin{array}{c}0.00657^{* *} \\
(0.00310)\end{array}$ \\
\hline $\begin{array}{l}\text { GDP per capita } \\
\text { (relative to US) }\end{array}$ & & & & & & & $\begin{array}{l}1.66 \mathrm{e}-05^{* * *} \\
(4.35 \mathrm{e}-06)\end{array}$ & $\begin{array}{c}2.40 \mathrm{e}-05^{* * *} \\
(6.01 \mathrm{e}-06)\end{array}$ & $\begin{array}{c}1.16 \mathrm{e}-05^{* * *} \\
(3.97 \mathrm{e}-06)\end{array}$ \\
\hline Log of real wage levels & & & & & & & & $\begin{array}{c}-0.595^{* * *} \\
(0.194)\end{array}$ & \\
\hline $\begin{array}{l}\text { Trade openness } \\
\text { (in percent of GDP) }\end{array}$ & & & & & & & & & $\begin{array}{c}-0.00503^{* * *} \\
(0.00189)\end{array}$ \\
\hline Constant & $\begin{array}{c}16.71^{* * *} \\
(6.099)\end{array}$ & $\begin{array}{c}12.00^{* * *} \\
(3.833)\end{array}$ & $\begin{array}{l}4.506 \\
(2.967)\end{array}$ & $\begin{array}{l}5.171^{*} \\
(3.084)\end{array}$ & $\begin{array}{c}2.884 \\
(1.932)\end{array}$ & $\begin{array}{c}2.402 \\
(1.921)\end{array}$ & $\begin{array}{c}15.49^{* * *} \\
(4.002)\end{array}$ & $\begin{array}{c}18.24^{* * *} \\
(4.879)\end{array}$ & $\begin{array}{c}10.47^{* * *} \\
(3.287)\end{array}$ \\
\hline Observations & 2,284 & 2,278 & 1,820 & 1,450 & 1,820 & 1,741 & 1,484 & 1,528 & 1,480 \\
\hline Number of countries & 139 & 139 & 120 & 107 & 120 & 115 & 92 & 92 & 92 \\
\hline Number of instruments & 47 & 81 & 83 & 61 & 104 & 104 & 103 & 131 & 131 \\
\hline Time dummies & No & No & No & No & Yes & Yes & Yes & Yes & Yes \\
\hline Sargan test & 44.63 & 86.28 & 86.18 & $69.40^{*}$ & 75.30 & 68.17 & 78.58 & 120.7 & 118.6 \\
\hline
\end{tabular}

Note: Dynamic estimates using Arellano-Bond GMM estimator. Equations 5-9 contain time dummies. Standard errors in parentheses. ${ }^{* * *} \mathrm{p}<0.01,{ }^{* *} \mathrm{p}<0.05,{ }^{*} \mathrm{p}<0.1$.

Breaking down the overall effect of remittances on male versus female participation rates, the negative impact seems to be weaker for men than for women (see Tables 3 and 4). Without any further controls, remittances even seem to positively affect male participation rates. Especially when controlling for time dummies, investment, relative GDP per capita levels, trade openness and real wages, estimated elasticities of female participation rates with respect to remittances are larger than those for men and with higher significance levels (see equations (7) and (8) in Tables 3 and 4). ${ }^{11}$ This is in line with findings in other labor supply studies that indicate more elastic female participation rates across a number of policy and economic variables (e.g. taxes, wages, etc.) than male rates.

\footnotetext{
${ }^{11}$ Instead of running regressions separately for male and female labor force participation rates, we also tried to analyse the participation gap (i.e. the percentage pont difference in male and female labor force participation rates). Given the heterogenous reaction of the two groups with respect to remittances, the corresponding coefficient was significant only in the simplest of specifications (results available from authors upon request).
} 
Table 3: Dependent variable: Male labor force participation rate

\begin{tabular}{|c|c|c|c|c|c|c|c|c|c|}
\hline Controls & $\begin{array}{c}(1) \\
\text { Remittances }\end{array}$ & $\begin{array}{c}(2) \\
\text { Working-age } \\
\text { population }\end{array}$ & $\begin{array}{c}(3) \\
\text { All income } \\
\text { flows }\end{array}$ & $\begin{array}{c}(4) \\
\text { +Liquid } \\
\text { liabilities }\end{array}$ & $\begin{array}{c}(5) \\
\text { All income } \\
\text { flows }\end{array}$ & $\begin{array}{c}(6) \\
\text { All income flows } \\
\text { Non-OECD countries }\end{array}$ & $\begin{array}{c}(7) \\
\text { All controls: } \\
\text { Wage growth }\end{array}$ & $\begin{array}{c}(8) \\
\text { All controls: } \\
\text { Wage levels }\end{array}$ & $\begin{array}{c}(9) \\
\text { All controls: } \\
\text { Trade openness }\end{array}$ \\
\hline $\begin{array}{l}\text { Labor force participation } \\
\text { rate (lagged) }\end{array}$ & $\begin{array}{l}0.895^{* * *} \\
(0.0586)\end{array}$ & $\begin{array}{l}0.754^{* * *} \\
(0.0559)\end{array}$ & $\begin{array}{l}0.681^{* * *} \\
(0.0565)\end{array}$ & $\begin{array}{l}0.694^{* * *} \\
(0.0592)\end{array}$ & $\begin{array}{c}0.906^{* * *} \\
(0.0368)\end{array}$ & $\begin{array}{l}0.897^{* * *} \\
(0.0362)\end{array}$ & $\begin{array}{l}0.848^{* * *} \\
(0.0573)\end{array}$ & $\begin{array}{l}0.838^{* * *} \\
(0.0518)\end{array}$ & $\begin{array}{c}0.954^{* * *} \\
(0.146)\end{array}$ \\
\hline $\begin{array}{l}\text { Working-age population } \\
\text { (in \% of total population) }\end{array}$ & & $\begin{array}{l}-0.00367^{*} \\
(0.00191)\end{array}$ & $\begin{array}{l}-0.00301 \\
(0.00194)\end{array}$ & $\begin{array}{l}-0.00295 \\
(0.00242)\end{array}$ & $\begin{array}{l}-0.00298 \\
(0.00228)\end{array}$ & $\begin{array}{l}-0.00314 \\
(0.00226)\end{array}$ & $\begin{array}{c}-0.00738^{* *} \\
(0.00287)\end{array}$ & $\begin{array}{c}-0.00613^{* *} \\
(0.00261)\end{array}$ & $\begin{array}{l}-0.00201 \\
(0.00565)\end{array}$ \\
\hline $\begin{array}{l}\text { Remittances } \\
\text { (as a share of GDP) }\end{array}$ & $\begin{array}{l}0.854^{*} \\
(0.510)\end{array}$ & $\begin{array}{c}0.535 \\
(0.496)\end{array}$ & $\begin{array}{c}-1.493^{* * *} \\
(0.422)\end{array}$ & $\begin{array}{c}-2.653^{* * *} \\
(0.759)\end{array}$ & $\begin{array}{c}-0.734^{*} \\
(0.424)\end{array}$ & $\begin{array}{c}-0.839^{* *} \\
(0.411)\end{array}$ & $\begin{array}{l}-1.567^{*} \\
(0.886)\end{array}$ & $\begin{array}{c}-2.013^{* *} \\
(0.825)\end{array}$ & $\begin{array}{l}-0.529 \\
(1.020)\end{array}$ \\
\hline $\begin{array}{l}\text { Official aid } \\
\text { (as a share of GDP) }\end{array}$ & & & $\begin{array}{c}0.0127^{*} \\
(0.00668)\end{array}$ & $\begin{array}{c}0.0106 \\
(0.00661)\end{array}$ & $\begin{array}{l}-0.00404 \\
(0.00791)\end{array}$ & $\begin{array}{l}-0.00437 \\
(0.00772)\end{array}$ & & & \\
\hline $\begin{array}{l}\text { FDI } \\
\text { (as a share of GDP) }\end{array}$ & & & $\begin{array}{c}-4.225^{* * *} \\
(0.811)\end{array}$ & $\begin{array}{c}-4.987^{* * *} \\
(0.972)\end{array}$ & $\begin{array}{l}-0.417 \\
(0.434)\end{array}$ & $\begin{array}{l}-0.533 \\
(0.448)\end{array}$ & & & \\
\hline $\begin{array}{l}\text { Liquid liabilities } \\
\text { (as a share of GDP) }\end{array}$ & & & & $\begin{array}{c}0.00170 \\
(0.00192)\end{array}$ & & & & & \\
\hline $\begin{array}{l}\text { Total investment } \\
\text { (as a share of GDP) }\end{array}$ & & & & & & & $\begin{array}{c}0.00195 \\
(0.00293)\end{array}$ & $\begin{array}{l}-0.00338 \\
(0.00476)\end{array}$ & $\begin{array}{c}0.00299 \\
(0.00536)\end{array}$ \\
\hline Real wage growth & & & & & & & $\begin{array}{r}-0.000355 \\
(0.00332)\end{array}$ & & $\begin{array}{c}0.00161 \\
(0.00754)\end{array}$ \\
\hline $\begin{array}{l}\text { GDP per capita } \\
\text { (relative to US) }\end{array}$ & & & & & & & $\begin{array}{c}2.43 \mathrm{e}-05^{* * *} \\
(8.00 \mathrm{e}-06)\end{array}$ & $\begin{array}{c}2.74 \mathrm{e}-05^{* * *} \\
(7.93 \mathrm{e}-06)\end{array}$ & $\begin{array}{c}9.78 \mathrm{e}-06 \\
(1.69 \mathrm{e}-05)\end{array}$ \\
\hline Log of real wage levels & & & & & & & & $\begin{array}{c}-0.206^{* *} \\
(0.103)\end{array}$ & \\
\hline $\begin{array}{l}\text { Trade openness } \\
\text { (in percent of GDP) }\end{array}$ & & & & & & & & & $\begin{array}{l}-0.00240 \\
(0.00727)\end{array}$ \\
\hline Constant & $\begin{array}{l}7.739^{*} \\
(4.388)\end{array}$ & $\begin{array}{c}20.84^{* * *} \\
(5.348)\end{array}$ & $\begin{array}{c}26.35^{* * *} \\
(5.297)\end{array}$ & $\begin{array}{c}25.64^{* * *} \\
(5.754)\end{array}$ & $\begin{array}{l}9.170^{* *} \\
(4.237)\end{array}$ & $\begin{array}{l}10.03^{* *} \\
(4.151)\end{array}$ & $\begin{array}{c}16.61^{* * *} \\
(6.162)\end{array}$ & $\begin{array}{c}18.41^{* * *} \\
(5.966)\end{array}$ & $\begin{array}{c}4.904 \\
(15.32)\end{array}$ \\
\hline Observations & 2,284 & 2,278 & 1,820 & 1,450 & 1,820 & 1,741 & 1,484 & 1,528 & 1,480 \\
\hline Number of countries & 139 & 139 & 120 & 107 & 120 & 115 & 92 & 92 & 92 \\
\hline Number of instruments & 47 & 81 & 83 & 61 & 104 & 104 & 103 & 131 & 27 \\
\hline Time dummies & No & No & No & No & Yes & Yes & Yes & Yes & Yes \\
\hline Sargan test & 58.93 & 128.1 & 98.54 & 89.76 & 89.52 & 95.18 & 130.3 & 174.2 & 0.167 \\
\hline
\end{tabular}

Note: Dynamic estimates using Arellano-Bond GMM estimator. Equations 5-9 contain time dummies. Standard errors in parentheses. ${ }^{* * *} \mathrm{p}<0.01,{ }^{* *} \mathrm{p}<0.05,{ }^{*} \mathrm{p}<0.1$.

One noteworthy finding from these estimations is that remittances tend to have both larger (in absolute value) and more consistently significant impacts on labor force participation rates than FDI and ODA have. This result suggests that remittances may also have larger impacts than FDI or ODA on other labor-market outcomes as well, and indeed we have already seen above that this is true for the unemployment rate. To the extent that remittances generally have a greater impact on labor markets than FDI or ODA, policymakers may need to adjust both the focus and the execution of both their development policies in general and their labor-market policies in particular to take remittances' effects into account. 
Table 4: Dependent variable: Female labor force participation rate

\begin{tabular}{|c|c|c|c|c|c|c|c|c|c|}
\hline Controls & $\begin{array}{c}(1) \\
\text { Remittances }\end{array}$ & $\begin{array}{c}(2) \\
\text { Working-age } \\
\text { population }\end{array}$ & $\begin{array}{c}(3) \\
\text { All income } \\
\text { flows }\end{array}$ & $\begin{array}{c}(4) \\
\text { +Liquid } \\
\text { liabilities }\end{array}$ & $\begin{array}{c}(5) \\
\text { All income } \\
\text { flows }\end{array}$ & $\begin{array}{c}(6) \\
\text { All income flows } \\
\text { Non-OECD countries }\end{array}$ & $\begin{array}{c}(7) \\
\text { All controls: } \\
\text { Wage growth }\end{array}$ & $\begin{array}{c}(8) \\
\text { All controls: } \\
\text { Wage levels }\end{array}$ & $\begin{array}{c}(9) \\
\text { All controls: } \\
\text { Trade openness }\end{array}$ \\
\hline $\begin{array}{l}\text { Labor force participation } \\
\text { rate (lagged) }\end{array}$ & $\begin{array}{l}0.926^{* * *} \\
(0.0570)\end{array}$ & $\begin{array}{l}0.826^{* * *} \\
(0.0476)\end{array}$ & $\begin{array}{c}0.908^{* * *} \\
(0.0419)\end{array}$ & $\begin{array}{l}0.927^{* * *} \\
(0.0395)\end{array}$ & $\begin{array}{c}0.973^{* * *} \\
(0.0210)\end{array}$ & $\begin{array}{l}0.976^{* * *} \\
(0.0203)\end{array}$ & $\begin{array}{c}0.886^{* * *} \\
(0.0450)\end{array}$ & $\begin{array}{l}0.886^{* * *} \\
(0.0433)\end{array}$ & $\begin{array}{l}0.925^{* * *} \\
(0.0355)\end{array}$ \\
\hline $\begin{array}{l}\text { Working-age population } \\
\text { (in \% of total population) }\end{array}$ & & $\begin{array}{c}0.00490^{* *} \\
(0.00233)\end{array}$ & $\begin{array}{c}0.00376 \\
(0.00277)\end{array}$ & $\begin{array}{c}0.00155 \\
(0.00371)\end{array}$ & $\begin{array}{c}0.00376 \\
(0.00272)\end{array}$ & $\begin{array}{c}0.00315 \\
(0.00274)\end{array}$ & $\begin{array}{l}-0.00186 \\
(0.00270)\end{array}$ & $\begin{array}{c}0.00542 \\
(0.00382)\end{array}$ & $\begin{array}{l}0.000397 \\
(0.00257)\end{array}$ \\
\hline $\begin{array}{l}\text { Remittances } \\
\text { (as a share of GDP) }\end{array}$ & $\begin{array}{l}-4.527 \\
(3.019)\end{array}$ & $\begin{array}{c}-7.915^{* * *} \\
(1.995)\end{array}$ & $\begin{array}{c}-5.322^{* *} \\
(2.293)\end{array}$ & $\begin{array}{c}-3.618^{* *} \\
(1.803)\end{array}$ & $\begin{array}{l}-1.607 \\
(1.157)\end{array}$ & $\begin{array}{l}-1.619 \\
(1.209)\end{array}$ & $\begin{array}{c}-7.807^{* * *} \\
(1.918)\end{array}$ & $\begin{array}{c}-6.251^{* * *} \\
(2.253)\end{array}$ & $\begin{array}{c}-4.552^{* *} \\
(1.768)\end{array}$ \\
\hline $\begin{array}{l}\text { Official aid } \\
\text { (as a share of GDP) }\end{array}$ & & & $\begin{array}{l}0.0548^{* *} \\
(0.0252)\end{array}$ & $\begin{array}{c}0.0296 \\
(0.0235)\end{array}$ & $\begin{array}{l}0.0275 \\
(0.0192)\end{array}$ & $\begin{array}{c}0.0225 \\
(0.0182)\end{array}$ & & & \\
\hline $\begin{array}{l}\text { FDI } \\
\text { (as a share of GDP) }\end{array}$ & & & $\begin{array}{l}-0.139 \\
(0.789)\end{array}$ & $\begin{array}{l}0.877 \\
(0.955)\end{array}$ & $\begin{array}{l}-0.849 \\
(0.707)\end{array}$ & $\begin{array}{l}-0.807 \\
(0.740)\end{array}$ & & & \\
\hline $\begin{array}{l}\text { Liquid liabilities } \\
\text { (as a share of GDP) }\end{array}$ & & & & $\begin{array}{l}-0.0136^{* *} \\
(0.00687)\end{array}$ & & & & & \\
\hline $\begin{array}{l}\text { Total investment } \\
\text { (as a share of GDP) }\end{array}$ & & & & & & & $\begin{array}{c}0.0113^{*} \\
(0.00630)\end{array}$ & $\begin{array}{l}-0.00157 \\
(0.00632)\end{array}$ & $\begin{array}{c}0.00454 \\
(0.00585)\end{array}$ \\
\hline Real wage growth & & & & & & & $\begin{array}{l}0.0145^{* *} \\
(0.00611)\end{array}$ & & $\begin{array}{c}0.00777 \\
(0.00538)\end{array}$ \\
\hline $\begin{array}{l}\text { GDP per capita } \\
\text { (relative to US) }\end{array}$ & & & & & & & $\begin{array}{c}6.19 \mathrm{e}-06 \\
(4.73 \mathrm{e}-06)\end{array}$ & $\begin{array}{l}9.00 \mathrm{e}-06^{*} \\
(4.66 \mathrm{e}-06)\end{array}$ & $\begin{array}{c}4.75 \mathrm{e}-06 \\
(4.92 \mathrm{e}-06)\end{array}$ \\
\hline Log of real wage levels & & & & & & & & $\begin{array}{l}-0.403^{*} \\
(0.228)\end{array}$ & \\
\hline $\begin{array}{l}\text { Trade openness } \\
\text { (in percent of GDP) }\end{array}$ & & & & & & & & & $\begin{array}{l}-0.00101 \\
(0.00173)\end{array}$ \\
\hline Constant & $\begin{array}{l}4.052 \\
(2.990)\end{array}$ & $\begin{array}{c}5.817^{* * *} \\
(1.751)\end{array}$ & $\begin{array}{l}2.197 \\
(2.104)\end{array}$ & $\begin{array}{c}3.295 \\
(2.345)\end{array}$ & $\begin{array}{l}-1.010 \\
(1.334)\end{array}$ & $\begin{array}{l}-0.716 \\
(1.351)\end{array}$ & $\begin{array}{c}7.224^{* * *} \\
(2.004)\end{array}$ & $\begin{array}{l}5.572^{* *} \\
(2.463)\end{array}$ & $\begin{array}{l}3.603^{*} \\
(1.950)\end{array}$ \\
\hline Observations & 2,284 & 2,278 & 1,820 & 1,450 & 1,820 & 1,741 & 1,484 & 1,528 & 1,480 \\
\hline Number of countries & 139 & 139 & 120 & 107 & 120 & 115 & 92 & 92 & 92 \\
\hline Number of instruments & 47 & 81 & 83 & 61 & 104 & 104 & 103 & 131 & 131 \\
\hline Time dummies & No & No & No & No & Yes & Yes & Yes & Yes & Yes \\
\hline Sargan test & 41.15 & 93.19 & 91.74 & 61.47 & 82.78 & 75.71 & 78.44 & 119.2 & 119 \\
\hline
\end{tabular}

Note: Dynamic estimates using Arellano-Bond GMM estimator. Equations 5-9 contain time dummies. Standard errors in parentheses. ${ }^{* * *} \mathrm{p}<0.01,{ }^{* *} \mathrm{p}<0.05,{ }^{*} \mathrm{p}<0.1$.

In order to get a better sense of the impact of the different control variables on labor supply across our sample, we also run quantile regressions. Figure 1 depicts the marginal effects of each of the four independent control variables that have been retained in Table 2, conditional on different quantiles of the dependent variable. As the chart demonstrates, the impact of remittances on labor supply is particularly strong at very high levels of labor force participation rates as well as at lower quantiles. At both ends of the distribution of labor force participation rates, countries with high levels of remittances inflows can be found with strong regional variations: whereas most countries with high labor force participation rates can be found in Sub-Saharan Africa and South and South-East Asia (Burkina Faso, Nepal, Cambodia), those receiving countries with low participation rates are mostly found in the Middle East and North Africa (e.g. Jordan, Lebanon, Egypt). In these two groups of countries, high shares of remittances to GDP depress labor supply significantly (see Figure 1, Panel A). Interestingly, in the same group of countries, foreign direct investment leads to a significant increase in labor supply (see Figure 1, Panel B), but it is only in countries with already high levels of labor force participation rates that official aid seems to further increase them (see Figure 1, Panel C). 
Figure 1: Labor force participation rates - Quantile regressions

Panel A: Remittances

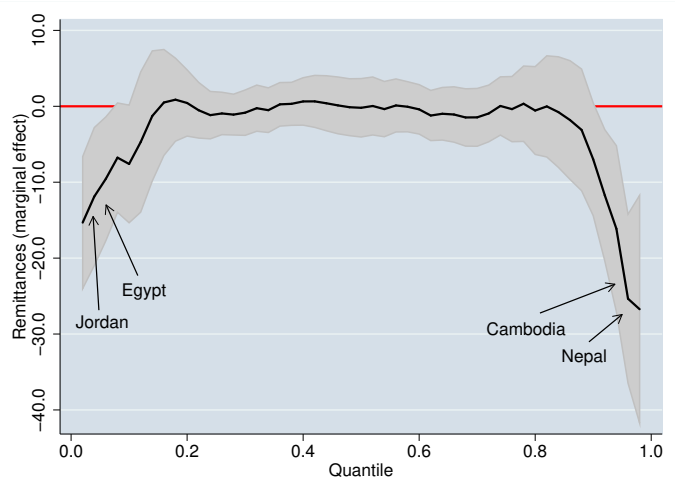

Panel C: Official development aid

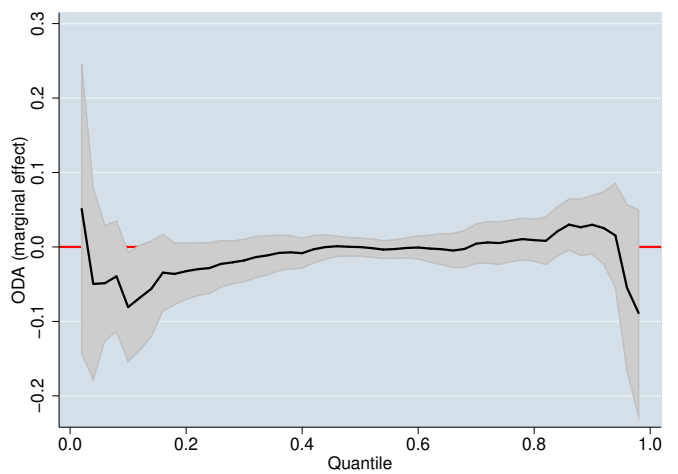

Panel B: Foreign direct investment

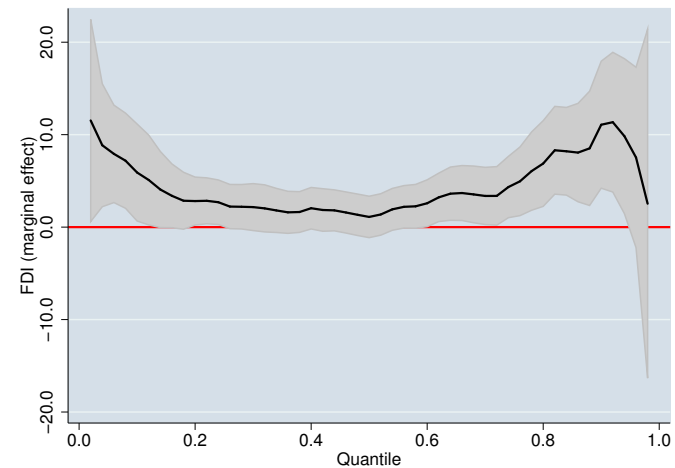

Panel D: Liquid liabilities

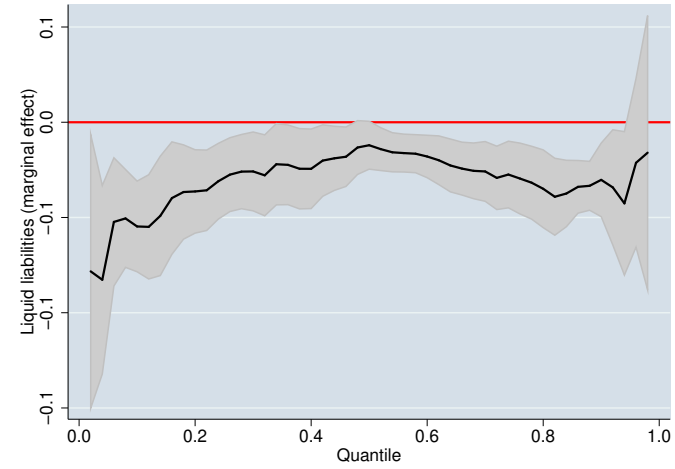

Note: The figure presents the effect of different income and capital flows on labor force participation rates for different quantiles of participation. The figure demonstrates that for both remittances and foreign direct investment, effects are largest (and significant) only for either very large or very low rates of labor force participation. In contrast, effects are more homogeneous across quantiles for both official development aid and changes in liquid liabilities.

As labor demand increases (as demonstrated by the fall in unemployment) and labor supply declines (with a fall in labor force participation), we would a priori expect an increase in wage growth that reflects this relative shift of supply and demand in the labor market. In the next section, we will verify directly whether this is indeed the case.

\subsection{Wages and inequality}

\subsubsection{Do remittances lift wages?}

An alternative way to measure the impact of remittances on labor outcomes is by looking at the evolution of wages. Even more than in the case of data on employment and labor force participation, the availability of wage data is patchy for low- and 
middle-income countries. Most people in the informal labor market do not report labor earnings and available wage data in these countries is limited to some formal sector enterprises, significantly over-estimating the average wage level. In order to remedy these biases in the available - official - wage data, Ernst et al. (2016) have recently put together a new wage database, using existing wage data with theoretical considerations in order to better take into account the size of the informal economy and the spread of working poverty to generate improved estimates of the dynamics of labor earnings.

In order to estimate the impact of remittances on (real) wage growth, we (re-) interpret equation (1) as a wage Phillips curve augmented with the (lagged) shares of remittances. Given that labor supply and demand factors are being controlled for in such a specification, remittances act as a shifter on the wage bargaining coefficient that indicates how much of the joint matching rent can be appropriated by the labor demand side. ${ }^{12}$

Estimating the impact of remittances on wages potentially runs into reverse causality issues as low wages might induce higher out-migration and hence a higher share of remittances flowing back into the economy. In order to (partially) remedy these issues, we lagged the remittances share by one period. Table 5 reports the results of various specifications of an otherwise standard wage inflation equation, including either investment demand or unemployment (or both) as the proxy variable for labor demand that influences wage growth. Shifts in labor supply that influence the evolution of wages are being taken into account using information on changes in the labor force participation rates.

Across all specifications, the share of remittances to GDP exerts downward pressure on aggregate wage growth, in contrast to what would have been expected from the shifts on labor demand and supply induced by remittances as analyzed in the previous section. Interpreting the results suggests that remittances might actually lower the pressure from workers asking for a higher share of the matching rent. We will see in the following sections, however, that this might not be the only interpretation and that composition effects are possibly explaining the negative estimated coefficient.

\footnotetext{
${ }^{12}$ An alternative specification in levels (i.e. estimating a wage curve rather than a wage Phillips curve) leads essentially to the same conclusions. Results available from authors upon request.
} 
Table 5: Wage growth and remittances

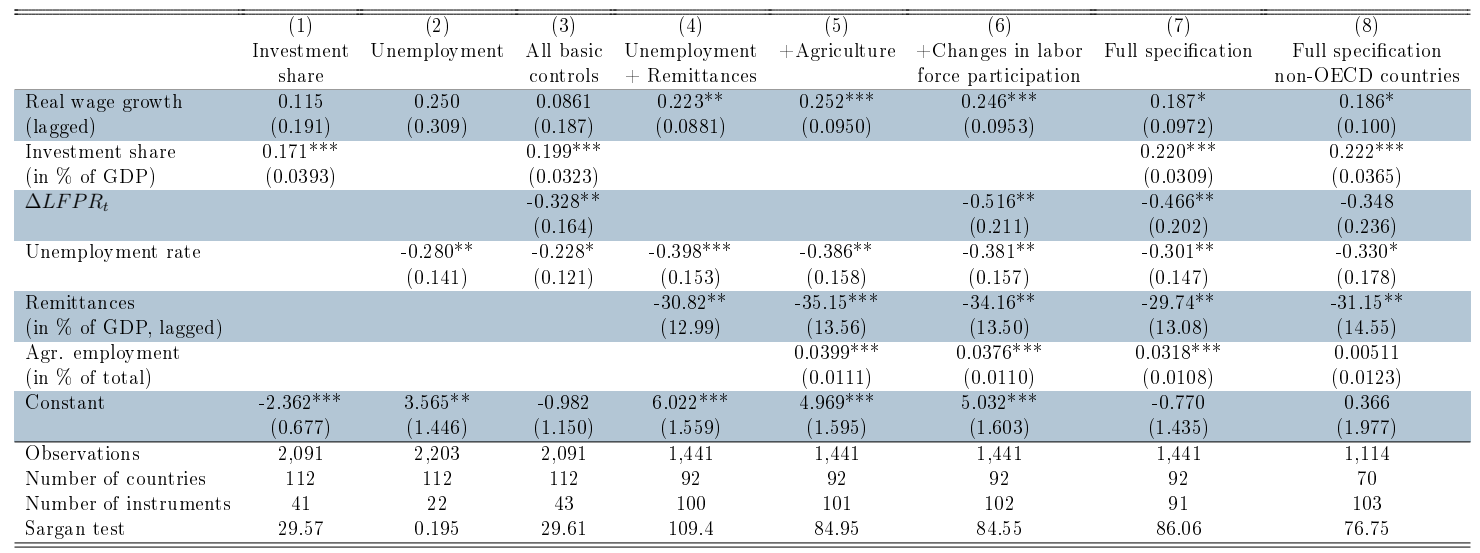

Note: Dynamic estimates using Arellano-Bond GMM estimator, assuming weak exogeneity for income flows. Year dummies included in all regressions. Standard errors in parentheses. *** $\mathrm{p}<0.01,{ }^{* *} \mathrm{p}<0.05,{ }^{*} \mathrm{p}<0.1$

Source: ILO Wage projection database (see Ernst et al., 2016); own calculations.

\subsubsection{Remittances and the labor income share}

The slowdown in wage growth may be indicating that the growth rate of labor productivity is also falling, or in other words that remittances reduce the growth of labor productivity. The most direct evidence of how remittances might affect wage growth in comparison to productivity is to look at their effect on labor's share of income. In particular, should productivity growth fall faster than wage growth, the labor income share would increase. In addition, in those countries where governments manage to control and tax (at least parts of) the remittances flow, public sector consumption for instance through higher public sector wages - might further contribute to a rise in the labor income share. ${ }^{13}$

In order to test such a relationship, Table 6 reports estimation results of the effect of remittances on changes in the labor income share in our sample, including various control variables and for the sub-sample of non-OECD countries. As the table demonstrates, remittances positively and significantly affect changes in labor income share across all specifications, indicating an increase in labor income share as the flow of remittances grows. Together with the results of the previous subsection, this suggests that remittances exercise a strong negative impact on productivity growth, over and above the one on wages.

\footnotetext{
${ }^{13}$ Given the nature of our data where only aggregate but not sectoral wage data is available, only indirect evidence for this type of transmission mechanism can be provided.
} 
Table 6: Change in the labor income share and remittances

\begin{tabular}{lccccc}
\hline \hline & $\begin{array}{c}(1) \\
\text { Investment } \\
\text { share }\end{array}$ & $\begin{array}{c}(2) \\
\text { Informal } \\
\text { employment }\end{array}$ & $\begin{array}{c}(3) \\
\text { Agricultural } \\
\text { employment }\end{array}$ & $\begin{array}{c}(4) \\
\text { Full specification } \\
\text { + time dummies }\end{array}$ & $\begin{array}{c}\text { Full specification: } \\
\text { non-OECD countries }\end{array}$ \\
\hline $\begin{array}{l}\text { Change in labor income share } \\
\text { (lagged) }\end{array}$ & -0.0268 & -0.0255 & -0.0243 & -0.0175 & -0.0320 \\
Investment share & $(0.0879)$ & $(0.0879)$ & $(0.0880)$ & $(0.0906)$ & $(0.0929)$ \\
(in \% of GDP) & $0.0631^{* * *}$ & $0.0692^{* * *}$ & $0.0689^{* * *}$ & $0.0805^{* * *}$ & $0.0877^{* * *}$ \\
Informal & $(0.0239)$ & $(0.0242)$ & $(0.0242)$ & $(0.0244)$ & $(0.0279)$ \\
employment & & $-0.0196^{* * *}$ & $-0.0771^{* * *}$ & $-0.0773^{* * *}$ & $-0.0805^{* * *}$ \\
Agricultural employment & & $(0.00711)$ & $(0.0168)$ & $(0.0168)$ & $(0.0188)$ \\
(in \% of total employment) & & & $0.0727^{* * *}$ & $0.0715^{* * *}$ & $0.0719^{* * *}$ \\
Remittances & $6.205^{* *}$ & $7.681^{* *}$ & $(0.0186)$ & $(0.0184)$ & $(0.0203)$ \\
(in \% of GDP) & $(2.956)$ & $(3.039)$ & $\left(3.047^{* *}\right.$ & $7.656^{* *}$ & $7.104^{* *}$ \\
Constant & $-1.580^{* * *}$ & $-1.045^{*}$ & -0.786 & $-1.862^{* *}$ & $(3.395)$ \\
& $(0.596)$ & $(0.620)$ & $(0.621)$ & $(0.774)$ & $-1.827^{*}$ \\
& 1,441 & 1,441 & 1,441 & 1,441 & $(0.994)$ \\
\hline Observations & 92 & 92 & 92 & 92 & 1,114 \\
Number of countries & 108 & 109 & 110 & 128 & 70 \\
Number of instruments & 113 & 113.1 & 113.2 & 103.6 & 96.77 \\
Sargan test & No & No & No & Yes & Yes \\
Time dummies & \multicolumn{3}{c}{} & \\
\hline \hline
\end{tabular}

Note: Dynamic estimates using Arellano-Bond GMM estimator, assuming weak exogeneity for income flows. Year dummies included in specifications (4) and (5). Standard errors in parentheses. *** $\mathrm{p}<0.01,{ }^{* *} \mathrm{p}<0.05,{ }^{*} \mathrm{p}<0.1$

Source: ILO Wage projection database (see Ernst et al., 2016); own calculations.

\subsubsection{How does inequality evolve?}

A further indication of how remittances affect the distribution of incomes and, hence, the average dynamics of wages comes from a closer look at their impact on income distribution measures directly. Here, we make use of the Standardized World Income Inequality Database that contains estimates on Gini coefficients for 176 countries dating as far back as 1960. The database is making use of multiple imputation techniques as described in Solt (2016). As before, we present different specifications, including those limited to non-OECD countries (see table 7).

As the results in Table 7 document, remittances as a share of GDP enter significantly negatively in all different specifications. The size of the estimated coefficients only changes moderately across specifications and-if anything-increases in absolute terms when more controls are added (see specification (3)). 
Table 7: Determinants of market inequality

\begin{tabular}{|c|c|c|c|c|c|c|c|c|}
\hline & $\begin{array}{c}(1) \\
\text { Basic controls }\end{array}$ & $\begin{array}{c}(2) \\
\text { Basic controls } \\
+ \text { time dummies }\end{array}$ & $\begin{array}{c}(3) \\
\text { All controls }\end{array}$ & $\begin{array}{c}(4) \\
\text { All controls } \\
+ \text { time dummies }\end{array}$ & $\begin{array}{c}(5) \\
\text { Sectoral controls }\end{array}$ & $\begin{array}{c}(6) \\
\text { Sectoral controls } \\
+ \text { time dummies }\end{array}$ & $\begin{array}{c}(7) \\
\text { Full specification } \\
\text { non-OECD countries }\end{array}$ & $\begin{array}{c}(8) \\
\text { Full specification } \\
\text { non-OECD countries }\end{array}$ \\
\hline $\begin{array}{l}\text { Market inequality } \\
\text { (lagged) }\end{array}$ & $\begin{aligned} 0.815^{* * *} \\
(0.0568)\end{aligned}$ & $\begin{array}{l}0.865^{* * * *} \\
(0.0527)\end{array}$ & $\begin{array}{c}0.836^{* * *} \\
(0.0465)\end{array}$ & $\begin{array}{l}0.835^{* * *} \\
(0.0385)\end{array}$ & $\begin{array}{l}0.878^{* * *} \\
(0.0484)\end{array}$ & $\begin{array}{l}0.858^{* * * *} \\
(0.0395)\end{array}$ & $\begin{array}{l}0.873^{* * * *} \\
(0.0475)\end{array}$ & $\begin{array}{l}0.853^{* * *} \\
(0.0421)\end{array}$ \\
\hline $\begin{array}{l}\text { Share of working-age- } \\
\text { to-total population (in \%) }\end{array}$ & & & $\begin{array}{l}-0.0192^{* * *} \\
(0.00879)\end{array}$ & $\begin{array}{l}-0.0195^{* *} \\
(0.00773)\end{array}$ & $\begin{array}{r}-0.00882 \\
(0.00895)\end{array}$ & $\begin{array}{c}-0.0114 \\
(0.00763)\end{array}$ & $\begin{array}{l}-0.0118 \\
(0.0102)\end{array}$ & $\begin{array}{c}-0.0129 \\
(0.00881)\end{array}$ \\
\hline Export share (in \%) & & & $\begin{array}{c}-6.033^{* * * *} \\
(1.472)\end{array}$ & $\begin{array}{c}-6.365^{* * *} \\
(1.488)\end{array}$ & $\begin{array}{c}-3.219^{* * * *} \\
(1.245)\end{array}$ & $\begin{array}{c}-3.383^{* * * *} \\
(1.270)\end{array}$ & $\begin{array}{c}-3.117^{*} \\
(1.651)\end{array}$ & $\begin{array}{l}-2.419 \\
(1.666)\end{array}$ \\
\hline $\begin{array}{l}\text { GDP growth } \\
\text { (p.a., in \%) }\end{array}$ & & & $\begin{array}{c}-0.0212^{* * * *} \\
(0.00704)\end{array}$ & $\begin{array}{c}-0.0240^{* * *} \\
(0.00777)\end{array}$ & $\begin{array}{c}-0.0122^{* *} \\
(0.00616)\end{array}$ & $\begin{array}{c}-0.0152^{* *} \\
(0.00690)\end{array}$ & $\begin{array}{l}-0.00537 \\
(0.00610)\end{array}$ & $\begin{array}{l}-0.00601 \\
(0.00689)\end{array}$ \\
\hline $\begin{array}{l}\text { Agriculture, forestry, } \\
\text { hunting and fishing (\%) }\end{array}$ & & & & & $\begin{array}{c}0.00364 \\
(0.00358)\end{array}$ & $\begin{array}{c}0.00493 \\
(0.00343)\end{array}$ & $\begin{array}{c}0.00517 \\
(0.00384)\end{array}$ & $\begin{array}{l}0.00616^{*} \\
(0.00373)\end{array}$ \\
\hline Mining and quarrying (\%) & & & & & $\begin{array}{c}-0.150^{* * * * *} \\
(0.0392)\end{array}$ & $\begin{array}{c}-0.156^{* * * *} \\
(0.0359)\end{array}$ & $\begin{array}{c}-0.159^{* * * *} \\
(0.0423)\end{array}$ & $\begin{array}{c}-0.174^{* * * *} \\
(0.0398)\end{array}$ \\
\hline Manufacturing (\%) & & & & & $\begin{array}{c}0.0104^{*} \\
(0.00596)\end{array}$ & $\begin{array}{c}0.0105^{*} \\
(0.00585)\end{array}$ & $\begin{array}{l}0.0160^{* * * * *} \\
(0.00613)\end{array}$ & $\begin{array}{l}0.0134^{* *} \\
(0.00597)\end{array}$ \\
\hline $\begin{array}{l}\text { Accommodation and } \\
\text { restaurants (\%) }\end{array}$ & & & & & $\begin{array}{r}-0.00617 \\
(0.0145)\end{array}$ & $\begin{array}{r}-0.00453 \\
(0.0144)\end{array}$ & $\begin{array}{c}0.0257 \\
(0.0173)\end{array}$ & $\begin{array}{l}0.0328^{*} \\
(0.0170)\end{array}$ \\
\hline $\begin{array}{l}\text { Health and social } \\
\text { work activities (\%) }\end{array}$ & & & & & $\begin{array}{c}0.0221 \\
(0.0158)\end{array}$ & $\begin{array}{l}0.0280^{* * *} \\
(0.0136)\end{array}$ & $\begin{array}{c}0.0104 \\
(0.0198)\end{array}$ & $\begin{array}{c}0.0192 \\
(0.0182)\end{array}$ \\
\hline $\begin{array}{l}\text { Public administration and defense; } \\
\text { compulsory social security (\%) }\end{array}$ & & & & & $\begin{array}{r}-0.00935 \\
(0.00883)\end{array}$ & $\begin{array}{c}-0.0117 \\
(0.00844)\end{array}$ & $\begin{array}{c}-0.00940 \\
(0.00988)\end{array}$ & $\begin{array}{l}-0.0148 \\
(0.00946)\end{array}$ \\
\hline Other services (\%) & & & & & $\begin{array}{l}0.108^{* *} \\
(0.0511)\end{array}$ & $\begin{array}{l}0.131^{* * * *} \\
(0.0421)\end{array}$ & $\begin{array}{l}0.120^{* *} \\
(0.0532)\end{array}$ & $\begin{array}{l}0.142^{* * *} \\
(0.0476)\end{array}$ \\
\hline $\begin{array}{l}\text { Share of own-account } \\
\text { workers, total (\%) }\end{array}$ & $\begin{array}{l}-0.00102 \\
(0.00217)\end{array}$ & $\begin{array}{l}-0.00307 \\
(0.00202)\end{array}$ & $\begin{array}{c}-0.0126^{* * *} \\
(0.00305)\end{array}$ & $\begin{array}{c}-0.0128^{* * * *} \\
(0.00278)\end{array}$ & $\begin{array}{l}-0.00323 \\
(0.00233)\end{array}$ & $\begin{array}{l}-0.00376 \\
(0.00231)\end{array}$ & $\begin{array}{l}-0.00319 \\
(0.00238)\end{array}$ & $\begin{array}{l}-0.00322 \\
(0.00237)\end{array}$ \\
\hline Unemployment rate (\%) & $\begin{array}{l}0.0290^{* * * *} \\
(0.00858)\end{array}$ & $\begin{array}{l}0.0195^{* *} \\
(0.00788)\end{array}$ & $\begin{array}{l}0.0227^{* * * *} \\
(0.00632)\end{array}$ & $\begin{array}{l}0.0221^{* * * *} \\
(0.00583)\end{array}$ & $\begin{array}{l}0.0234^{* * * *} \\
(0.00723)\end{array}$ & $\begin{array}{l}0.0245^{* * * *} \\
(0.00642)\end{array}$ & $\begin{array}{l}0.0165^{* * * *} \\
(0.00512)\end{array}$ & $\begin{array}{l}0.0153^{\text {**** }} \\
(0.00481)\end{array}$ \\
\hline $\begin{array}{l}\text { Remittances } \\
\text { (share of GDP, in \%) }\end{array}$ & $\begin{array}{c}-3.284^{* * * *} \\
(1.070)\end{array}$ & $\begin{array}{c}-2.135^{* *} \\
(0.977)\end{array}$ & $\begin{array}{c}-3.452^{* * * *} \\
(1.122)\end{array}$ & $\begin{array}{c}-3.394^{* * * *} \\
(0.994)\end{array}$ & $\begin{array}{c}-1.824^{* *} \\
(0.874)\end{array}$ & $\begin{array}{c}-1.961^{* *} \\
(0.786)\end{array}$ & $\begin{array}{c}-1.801^{* *} \\
(0.837)\end{array}$ & $\begin{array}{c}-1.561^{* *} \\
(0.755)\end{array}$ \\
\hline Constant & $\begin{array}{l}8.203^{* * *} \\
(2.468)\end{array}$ & $\begin{array}{c}6.287^{* * * *} \\
(2.285)\end{array}$ & $\begin{array}{c}9.279^{* * * *} \\
(2.816)\end{array}$ & $\begin{array}{c}9.579^{* * *} \\
(2.347)\end{array}$ & $\begin{array}{l}5.459^{* *} \\
(2.433)\end{array}$ & $\begin{array}{c}6.601^{* * * *} \\
(1.989)\end{array}$ & $\begin{array}{l}5.674^{* *} \\
(2.454)\end{array}$ & $\begin{array}{c}6.668^{* * * *} \\
(2.136)\end{array}$ \\
\hline Observations & 1,751 & 1,751 & 1,745 & 1,745 & 1,745 & 1,745 & 1,403 & 1,403 \\
\hline Number of countries & 127 & 127 & 126 & 126 & 126 & 126 & 105 & 105 \\
\hline Number of instruments & 95 & 116 & 98 & 119 & 105 & 126 & 117 & 105 \\
\hline Sargan test & 72.21 & 66.13 & 66.87 & 58.38 & 68.60 & 61.97 & 81.74 & 77.91 \\
\hline Time dummies & No & Yes & No & Yes & No & Yes & No & Yes \\
\hline
\end{tabular}

Note: Dynamic estimates using Arellano-Bond GMM estimator, assuming weak exogeneity for income flows. Equations 7 and 8 limit the sample to actually observed data points. Standard errors in parentheses. ${ }^{* * *} \mathrm{p}<0.01,{ }^{* *} \mathrm{p}<0.05,{ }^{*} \mathrm{p}<0.1$.

\subsubsection{Do remittances increase informality?}

The above results suggest that an increased inflow of remittances increases the reservation wage, lifting labor demand and wages but leading to lower labor force participation. The rise in the reservation wage might also cause informal employment to increase. Using information on employment status in the Global Employment Trends database, we can test this hypothesis. Specifically, we test the impact of remittances on the share of vulnerable employment in total employment. Vulnerable employment is defined as the sum of own-account and contributing family workers. These categories cover very well the extent of informal employment, especially for low-income countries.

The specifications of the macro-economic determinants of informal employment follows the discussion in ILO and WTO (2009). In this literature, the single most important factor is the level of development, followed by the size and types of economic vulnerabilities an economy is facing (such as trade, inflation and public finance shocks). More detailed analysis would include tax and business regulation, which, however, is not widely available for our sample of countries. 
Looking at the results in Table 8, we can indeed detect a positive impact of remittances on the share of vulnerable employment. The effect is independent of a series of control variables, with the exception of including government debt that causes the number of observations to drop significantly. In all other cases, the effect is significantly positive.

Table 8: Remittances and informal employment

\begin{tabular}{|c|c|c|c|c|c|c|c|}
\hline & $\begin{array}{c}(1) \\
\text { Baseline }\end{array}$ & $\begin{array}{c}(2) \\
\text { GDP per capita }+ \\
\text { investment }\end{array}$ & $\begin{array}{c}\text { GDP per capita, } \\
+ \text { + investment } \\
+ \text { government debt }\end{array}$ & $\begin{array}{c}(4) \\
\text { GDP per capita, } \\
+ \text { investment } \\
+ \text { inflation } \\
\end{array}$ & $\begin{array}{l}\text { Full controls } \\
\text { Fis }\end{array}$ & $\begin{array}{c}(6) \\
\text { Baseline }+ \\
\text { time dummies }\end{array}$ & $\begin{array}{c}(7) \\
\text { Full controls }+ \\
\text { time dummies }\end{array}$ \\
\hline $\begin{array}{l}\text { Informal employment } \\
\text { (lagged) }\end{array}$ & $\begin{array}{c}0.131 \\
(0.0844)\end{array}$ & $\begin{array}{l}0.235^{* * *} \\
(0.0800)\end{array}$ & $\begin{array}{c}0.412^{* *} \\
(0.206)\end{array}$ & $\begin{array}{l}0.235^{* * *} \\
(0.0805)\end{array}$ & $\begin{array}{l}0.276^{* * *} \\
(0.0794)\end{array}$ & $\begin{array}{c}0.120 \\
(0.122)\end{array}$ & $\begin{array}{c}0.377^{* * *} \\
(0.0780)\end{array}$ \\
\hline $\begin{array}{l}\text { GDP per capita } \\
\text { (in logs) }\end{array}$ & $\begin{array}{c}-5.173^{* * *} \\
(0.493)\end{array}$ & $\begin{array}{c}-3.673^{* * *} \\
(0.451)\end{array}$ & $\begin{array}{c}-1.870^{* * *} \\
(0.644)\end{array}$ & $\begin{array}{c}-3.677^{* * *} \\
(0.458)\end{array}$ & $\begin{array}{c}-3.391^{* * *} \\
(0.456)\end{array}$ & $\begin{array}{c}-5.049^{* * *} \\
(0.644)\end{array}$ & $\begin{array}{c}-3.338^{* * *} \\
(0.481)\end{array}$ \\
\hline $\begin{array}{l}\text { Investment ratio } \\
\text { (in \% of GDP) }\end{array}$ & & $\begin{array}{c}-0.117^{* * *} \\
(0.0133)\end{array}$ & $\begin{array}{c}-0.0895^{* *} \\
(0.0374)\end{array}$ & $\begin{array}{c}-0.116^{* * *} \\
(0.0131)\end{array}$ & $\begin{array}{c}-0.145^{* * *} \\
(0.0175)\end{array}$ & & $\begin{array}{c}-0.119^{* * *} \\
(0.0140)\end{array}$ \\
\hline $\begin{array}{l}\text { Remittances } \\
\text { (in \% of GDP) }\end{array}$ & $\begin{array}{c}10.21^{* * *} \\
(1.904)\end{array}$ & $\begin{array}{c}11.73^{* * *} \\
(2.183)\end{array}$ & $\begin{array}{l}31.67^{* *} \\
(15.72)\end{array}$ & $\begin{array}{c}12.01^{* * *} \\
(2.208)\end{array}$ & $\begin{array}{c}10.41^{* * *} \\
(2.327)\end{array}$ & $\begin{array}{c}11.35^{* * *} \\
(2.446)\end{array}$ & $\begin{array}{c}7.352^{* * *} \\
(2.258)\end{array}$ \\
\hline $\begin{array}{l}\text { Government debt } \\
\text { (in \% of GDP) }\end{array}$ & & & $\begin{array}{c}0.0175^{* * *} \\
(0.00521)\end{array}$ & & & & \\
\hline Inflation rate & & & & $\begin{array}{c}4.25 \mathrm{e}-4^{* * *} \\
(1.35 \mathrm{e}-4)\end{array}$ & $\begin{array}{c}3.93 \mathrm{e}-4^{* * *} \\
(1.38 \mathrm{e}-4)\end{array}$ & & $\begin{array}{l}3.02 \mathrm{e}-4^{* *} \\
(1.42 \mathrm{e}-4)\end{array}$ \\
\hline $\begin{array}{l}\text { Import ratio } \\
\text { (in \% of GDP) }\end{array}$ & & & & & $\begin{array}{l}2.24 \mathrm{e}-2^{* *} \\
(8.71 \mathrm{e}-3)\end{array}$ & & $\begin{array}{l}1.90 \mathrm{e}-2^{* *} \\
(8.69 \mathrm{e}-3)\end{array}$ \\
\hline Constant & $\begin{array}{c}82.16^{* * *} \\
(7.620)\end{array}$ & $\begin{array}{c}67.40^{* * *} \\
(6.949) \\
\end{array}$ & $\begin{array}{c}38.13^{* * *} \\
(10.77) \\
\end{array}$ & $\begin{array}{c}67.44^{* * *} \\
(7.020) \\
\end{array}$ & $\begin{array}{c}62.88^{* * *} \\
(6.896) \\
\end{array}$ & $\begin{array}{c}81.59^{* * *} \\
(10.67)\end{array}$ & $\begin{array}{c}57.44^{* * *} \\
(7.296) \\
\end{array}$ \\
\hline Observations & 2,257 & 2,176 & 968 & 2,165 & 2,152 & 2,257 & 2,152 \\
\hline Number of countries & 139 & 132 & 73 & 132 & 131 & 139 & 131 \\
\hline Number of instruments & 39 & 40 & 20 & 41 & 42 & 52 & 63 \\
\hline Sargan test & 37.62 & 44.11 & 19.04 & 43.66 & 44.35 & 33.02 & 46.05 \\
\hline Time dummies & No & No & No & No & No & Yes & Yes \\
\hline
\end{tabular}

Note: Dynamic estimates using Arellano-Bond GMM estimator, assuming weak exogeneity for income flows. Year dummies included where indicated. Standard errors in parentheses. $* * * \mathrm{p}<0.01,{ }^{* *} \mathrm{p}<0.05,{ }^{*} \mathrm{p}<0.1$

Overall, the results of this section suggest that remittances have significant effects on the composition of the labor market in receiving countries. At first glance, the negative impacts of remittances on wage and productivity growth may seem difficult to reconcile with our finding that remittances reduce unemployment, especially if an increase in labor demand is at least partially responsible for the decline in unemployment. But these results can be reconciled by appealing to models of the labor market that are segmented by productivity or skill level and allow remittances to affect each market segment differently. For example, previous literature has found that remittances cause Dutch Disease effects in which remittances cause the less-productive nontradables sector to expand at the expense of the more-productive tradables sector. To the extent that the tradables sector is associated with high-wage and high-productivity labor (or high-skilled jobs) and the nontradables sector with low-wage and low-productivity labor (or low-skilled jobs), remittances could drive employment in the tradable sector down and employment in the nontradable sector up. If the employment gain in the latter sector is greater than the employment loss in the tradable sector, then the overall unemployment rate will decline, but measured wage and productivity growth will likely fall. All of these results are then due to composition effects. Our findings of an increase in informal employment due to an 
inflow in remittances support this conjecture.

\subsection{Sectoral shifts}

In order to further estimate the impact of remittances on potential output, in this section we report their impact on the sectoral composition of an economy. While not directly linked to estimates of factor efficiency, which - in our case - are not available due to the lack of data in most countries in our sample, shifts in sectoral employment patterns can nonetheless indicate whether capital and income flows generate structural transformation in favor of more productive uses of capital and labor.

To carry out these estimates, we use the ILO's Sectoral Employment database derived from the ILO's Trends Econometric Models (see ILO, 2010). For each of the 14 different sectors, an employment demand equation has been set up, using the methodology described in Section 3.1, in levels without a lagged dependent variable. Each sectoral demand equation has been estimated independently. Figure 2 provides an overview of the estimated (significant) coefficients for each of the 14 sectors.

As the chart demonstrates, an inflow of remittances is indeed associated with a significant shift in the sectoral employment structure. Employment flows out of agriculture and into service-oriented sectors. Interestingly, however, this shift does not provide a push towards more job creation in manufacturing. Instead, low-productive services such as accommodation and construction, as well as some higher value-added services in transportation and utilities benefit from this shift, which calls into question the overall impact of this structural transformation on the aggregate productivity level of the economy. 
Figure 2: Sectoral employment impact of remittances

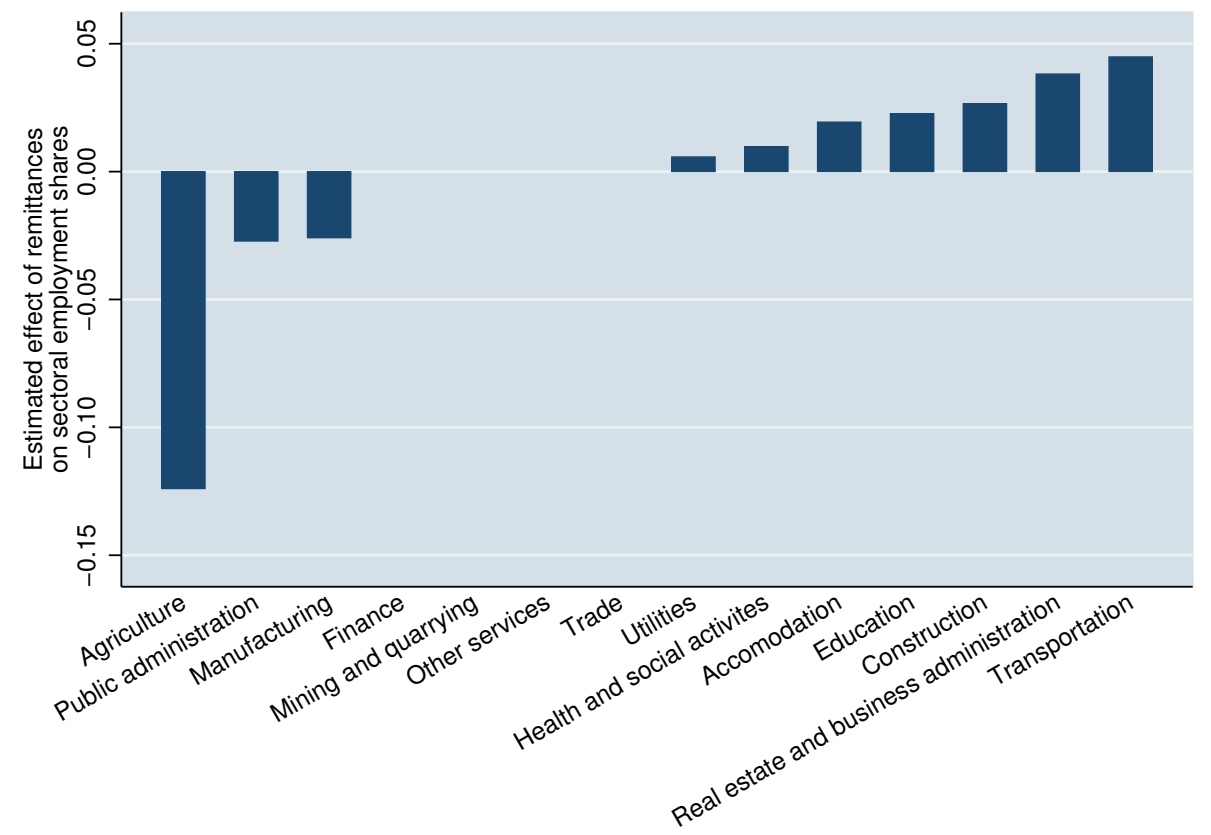

Note: The chart displays the coefficient of the effect of remittances (as a share of GDP) on sectoral employment (as a share of total employment). Only coefficients statistically significant at the $5 \%$ level are displayed, otherwise they are set to zero.

Source: Own calculations.

Moreover, a closer inspection of the impact of remittances on sectoral employment quantiles reveals that manufacturing employment seems to suffer particularly in those economies where there is a relatively high share of manufacturing jobs to begin with (Figure 3, Panel A). In contrast, employment in construction increases in those countries where the share of construction employment is intermediate or low (Figure 3, Panel B). A similar conclusion, but to a much lesser extent, holds for employment in financial services. Finally, employment in transport services, a capital-intensive sector but with low entry barriers, benefits across the board, independent of the starting conditions in a particular country. This might suggest that remittances are being used to set up (small-scale) transport services as a way to provide alternative income sources. 
Figure 3: Sectoral employment - Quantile regressions

Panel A. Manufacturing

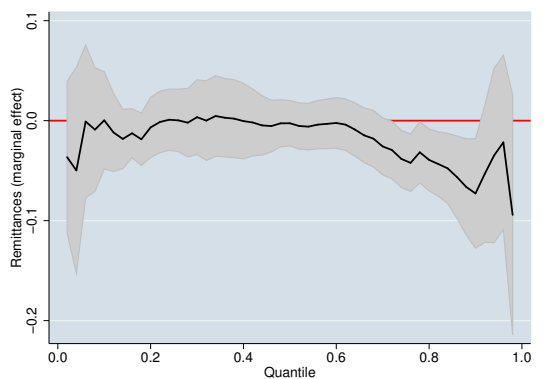

Panel C. Financial services

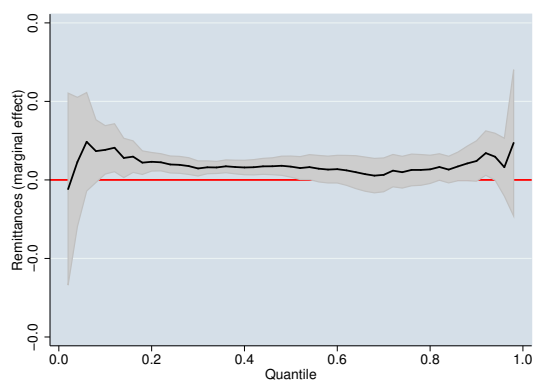

Panel B. Construction

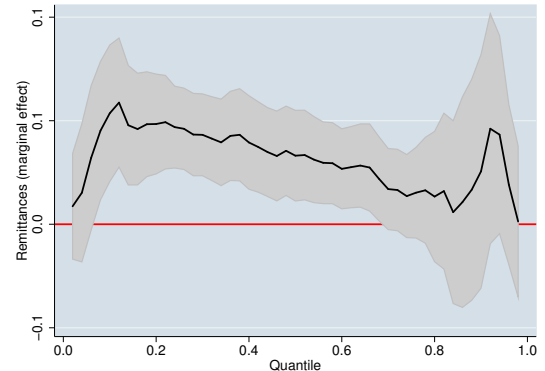

Panel D. Transportation

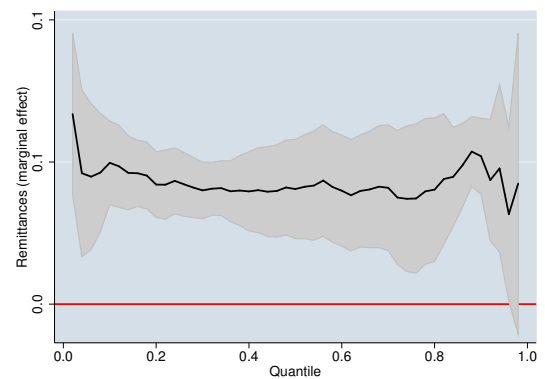

These results tend to confirm several of the findings from previous studies. Several studies discussed in Section 2 find that remittances tend to decrease the amount of effort that farmers put forth, which is consistent with our finding that agricultural employment is negatively affected by remittances. In addition, the negative impact on manufacturing employment could be consistent with the literature on the Dutch disease effects of remittances, depending on whether the output from local manufacturing is tradable or nontradable.

Those sectors in which employment increases, on the other hand, are generally associated with increased household expenditures from remittances. Many household surveys find that families spend remittance income on real estate purchases, including new homes and home improvements. These would clearly benefit the real estate, construction, and utilities sectors. Likewise, many household expenditure surveys report that families increase their spending on education and health care, particularly children's health.

Looking jointly at the aggregate and sectoral results, remittances appear to have strong compositional effects, which consistently reduce measured income inequality. In addition to their direct impact on recipient families' incomes, remittances could be associated with better economic performance across all income levels, and relatively greater increases for lower income earners than for higher income earners. But the results of the sectoral employment estimations, as well as the productivity and wage growth estimations, indicate that while lower income earners fare better as remittances increase, some higher income earners fare worse. This effect would help 
explain why remittances reduce poverty and inequality, but have not been found to enhance economic growth.

Up to this point in the paper, we have estimated remittances' average labor market impacts on all countries or on non-OECD countries. But these estimates may conceal interesting and important differences across countries, especially regional variations. In addition, there is increasing interest among policymakers in fragile states, and how their economies differ from more stable states. We therefore turn to examining whether remittances' labor market effects vary significantly by region or by the degree of fragility of the state whose residents are receiving them.

\subsection{Regional variation}

As the quantile regression results discussed above indicate, there may be systematic variation in remittances' effect by region. To explore this issue further, we have broken down the variation of the estimated coefficients and looked at their regional differences across 11 major subregions in our sample (see Table 10 in the Appendix for a regional breakdown and the countries covered by each region).

In order to account for the fact that some of the regions have rather small samples, we opted for two alternative approaches to estimate region-specific coefficients. One approach is to remove each region one at a time in order to estimate the difference between the coefficient in the full sample with that in the reduced sample; the other is to interact regional dummies with the share of remittances in GDP.

We use the first approach for Figure 4. The figure demonstrates significant crossregional divergence in the (absolute) impact of remittances on labor force participation. Note, however, than in all cases, the effective impact remains negative; only its absolute size differs across regions. A priori, regional differences in the impact of remittances should not be linked to the average labor force participation rate (high in Sub-Saharan Africa but low in MENA). These differences warrant further analysis that goes beyond the scope of this paper, however. 
Figure 4: Remittances and labor force participation by region

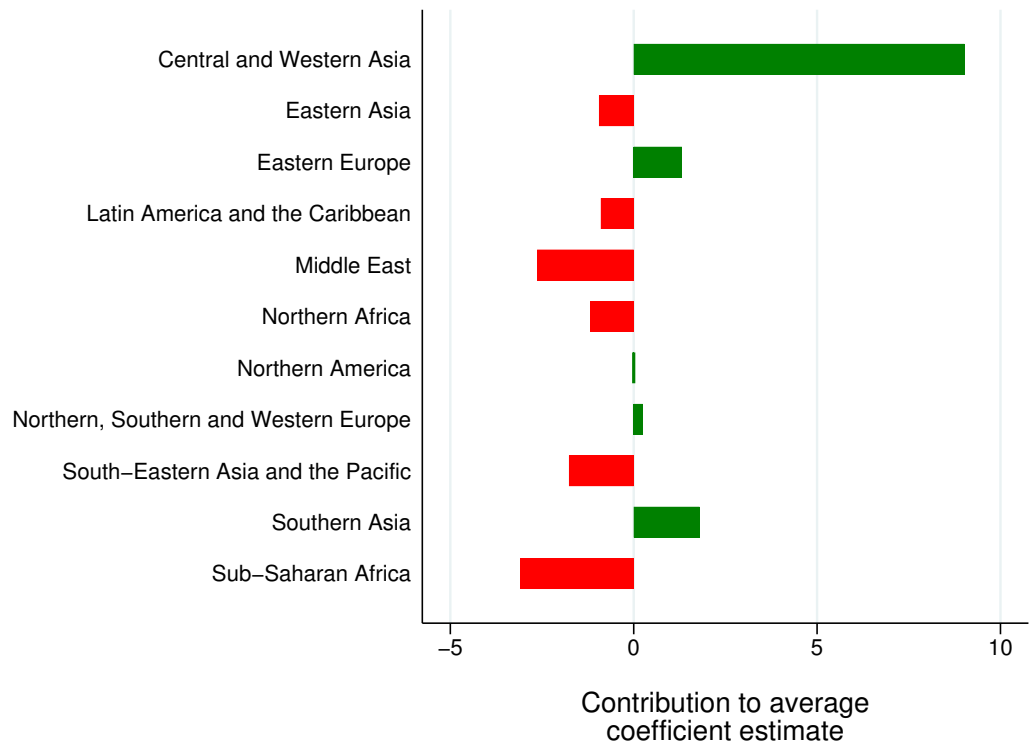

Note: The chart displays the contribution of each region to the average impact of remittances on the labor force participation rate when estimated using equation (6) in table 2. Red (negative) bars indicate that the region contributes to the average impact by increasing it in absolute value (i.e. making it more negative); green (positive) bars indicate the opposite. The effects have been estimated by removing one region at a time and reestimating the coefficient in the panel of remaining countries. All estimated coefficients are significant(ly negative).

Regional impacts of remittances on informal employment can also be estimated (see Figure 5). Using the same approach as before, we demonstrate significant regional variation in the impact of remittances in different regions. Whereas remittances increase informality more strongly in MENA, Sub-Saharan Africa and Central and Western Asia, they have a weaker impact in Eastern Europe and Southern Asia, as well as the Latin America and Caribbean region. This points to significant policy challenges in some regions to mitigate the impact of remittances on informality, which are unrelated to the size of the informal sector (MENA countries have on average a lower informality rate than countries in the Latin America and the Caribbean region: 16 per cent of total employment vs. 35 per cent). 
Figure 5: Remittances and informal employment by region

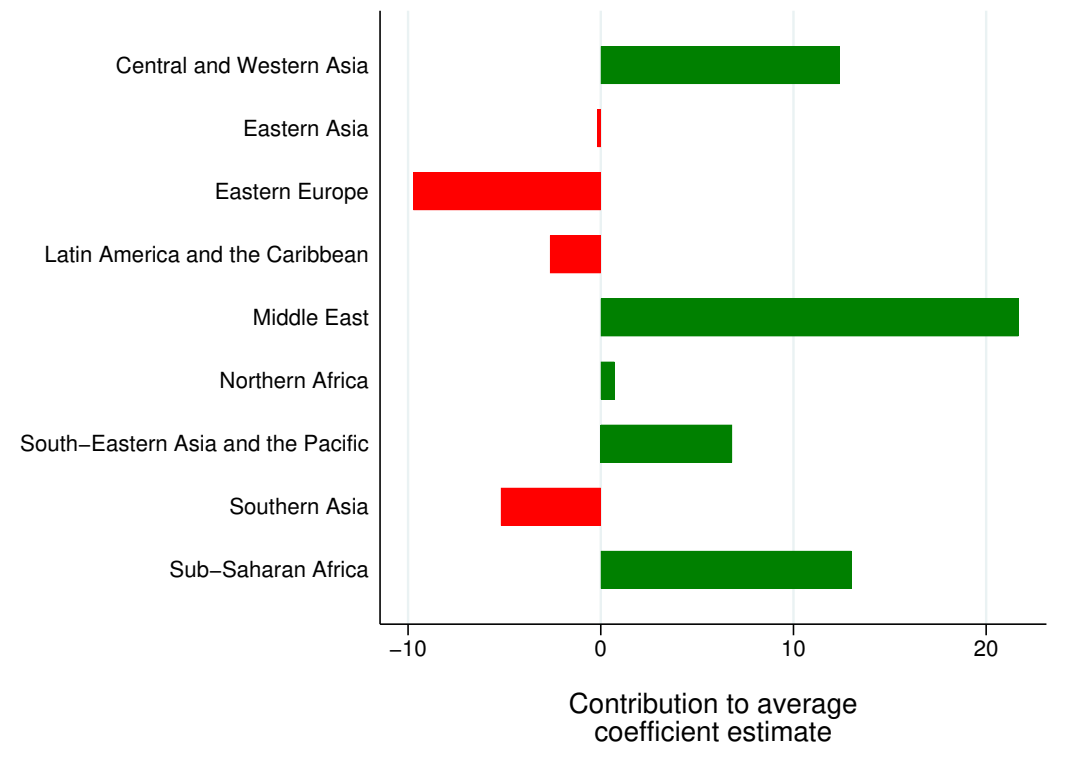

Note: The chart displays the contribution of each region to the average impact of remittances on the share of vulnerable employment when estimated using equation (5) in table 8 . Red (negative) bars indicate that the region contributes to the average impact by decreasing it in absolute value (i.e. making it less positive); green (positive) bars indicate the opposite. The effects have been estimated by removing one region at a time and reestimating the coefficient in the panel of remaining countries. All estimated coefficients are significant(ly positive).

We also analyze regional variation in the impact of remittances on wage growth (see Figure 6). Here, we use interaction terms between regional dummies and the share of remittances in GDP to estimate region-specific coefficients. Only those coefficients that are statistically significant are displayed in the figure. As before, significant regional variations in the impact of remittances can be observed. Positive effects are visible among (poorer) countries in South Asia and Sub-Saharan Africa but also in relatively more affluent countries in Eastern Europe. Negative effects dominate in Central and Western Asia and South-East Asia and the Pacific, which are also those regions that influence the average effect visible in Table 5. Overall, the sample size is too small to allow for other regions to display significant effects, however. 
Figure 6: Remittances and wages by region

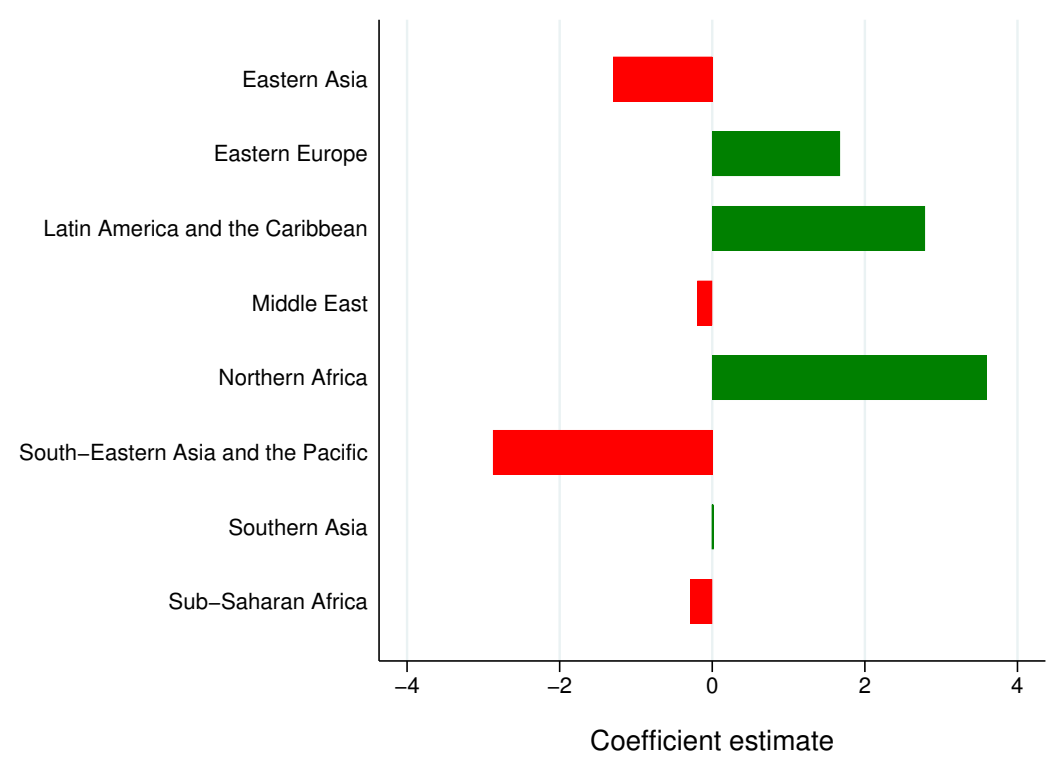

In addition to location, other country characteristics may be associated with variations in the effects of remittances on labor markets. One of these is the degree of the state's fragility. Fragile states often have large diasporas that remit funds to family members, suggesting that remittances may tend to be large relative to GDP in such states. In addition, the poor quality of social and political institutions in these countries may affect how remittances affect the economies of these nations. In addition, institutional quality may indirectly influence how remittances affect these nations by weakening their macroeconomic performance and reducing individual economic opportunity. For all these reasons, it is worth examining whether remittances affect fragile states' labor markets differently than those of more stable states. We turn to this next.

\subsection{Remittances in fragile states}

Although interest in fragile states is growing, no commonly agreed definition of state fragility exists. In the following estimations, we rely on the approach taken by the Fund for peace, the most comprehensive approach to date. Their approach relies on a multivariate analysis of information provided by official statistics, news analysis and expert assessment for each of the 178 countries forming their sample. ${ }^{14}$ For our purposes, we classify countries that fall within the quintile with the highest scores on the Fragile State Index as fragile. An average score has been used for the years

\footnotetext{
${ }^{14}$ For more details on the methodology used by the Fund for peace, refer to http:// fundforpeace.org/fsi/methodology/.
} 
between 2006 and $2017 .^{15}$

As a first approach, we estimate the impact of remittances on labor force participation rates separately for each quintile. The estimated coefficients of the impact of remittances on labor force participation rates have been summarized in Figure 7. As the figure demonstrates, the adverse effects of remittances on labor force participation are particularly strong for intermediate levels of fragility, further underlining the non-linear relationship between income flows and labor market outcomes. For very high levels of fragility, the impact declines but remains statistically significant, whereas for countries considered to be stable, this effect disappears.

Figure 7: Impact of remittances on labor force participation rates

(by degree of country fragility)

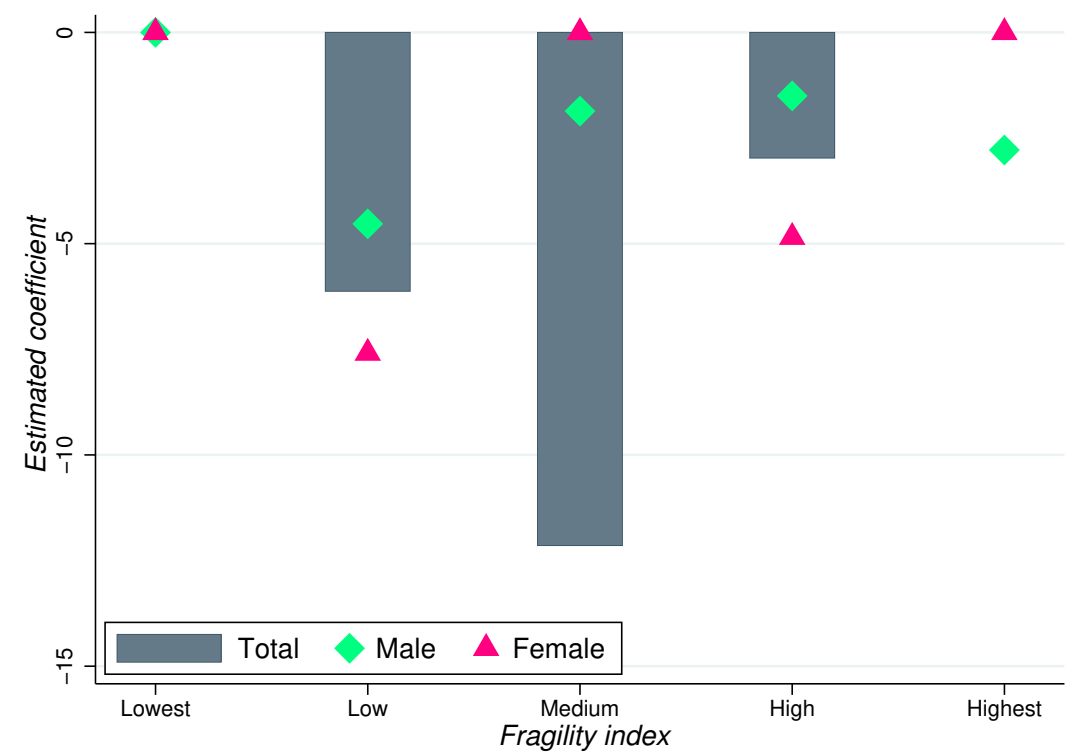

Note: The chart displays the estimated coefficients of the impact of remittances on labor force participation rates, using specification (6) of tables 2, 3 and 4 for total, male and female labor force participation rates respectively. Insignificant coefficients are represented by a zero value. Each bar/triangle/diamond represents the regression output by restricting the sample to those countries belonging to a particular quintile of the Fragile States Index average score between 2006 and 2017. Number of countries for each quintile of the average fragility index score: 4, 25, 30, 29, 28 (from lowest to highest quintiles).

Source: Own calculations; Fragile States Index taken from http://fundforpeace.org/ fsi/

Next we analyze the impact of remittances on wages and inequality in fragile states. To do this, we interacted the remittances' share of GDP with a dummy variable, indicating whether a country belonged to the group of highly fragile countries. This approach prevented us from analyzing the differences in impacts in more detail across the full range of fragile states, but given the limited sample size, splitting the

\footnotetext{
${ }^{15}$ The score changes very little over the indicated time period and exhibits an auto-correlation of $85 \%$.
} 
sample as before was not an option for these variables. Figure 8 summarizes the coefficient estimates, measured in natural logarithms. As the chart indicates, the impact of remittances on inequality does not seem to depend on the degree of country fragility, and indeed the difference in the size of the coefficient on remittances is not statistically significant for fragile versus stable countries. In contrast, real wage growth reacts very differently depending on whether remittances flow into fragile or stable countries. A possible explanation is that because of their overall lower level of economic development and the absence of a large tradable sector, the Dutch disease effect is absent or less pronounced in fragile states. Therefore, remittances can lift real wages rather than simply shift resources from the tradable to the nontradable sector.

Figure 8: The impact of remittances on wage growth and inequality

(by degree of country fragility)

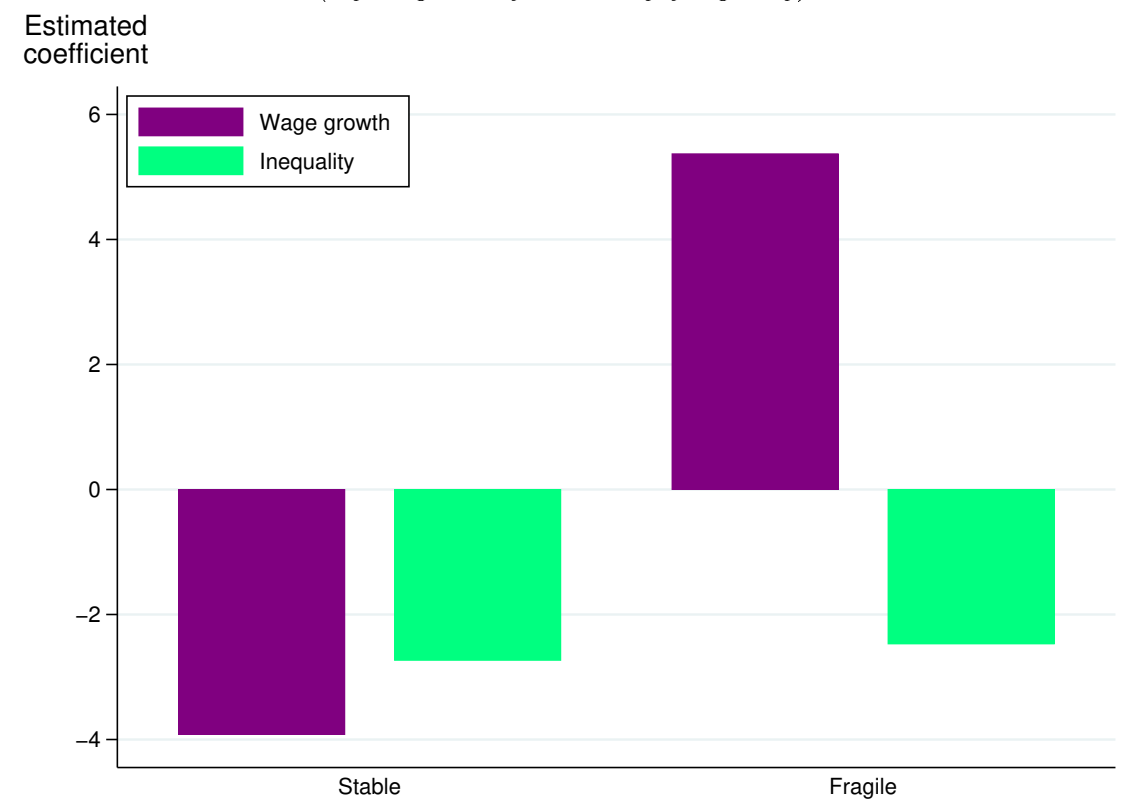

Note: The chart displays the estimated coefficients of the impact of remittances on wage growth (purple bars) and market inequality (green bars), using specification (6) of tables 5 and 7 for real wage growth and the Gini coefficient, respectively. A country is considered fragile if it belongs to the highest quintile according to our fragile states index. Coefficients have been estimated interacting the share of remittances as a percentage of GDP with a dummy variable indicating whether a country is fragile or not. Coefficients are displayed in natural logarithms. All estimates are significant at least at the $5 \%$ level.

Source: Own calculations; Fragile states index taken from http://fundforpeace.org/ fsi/

One piece of supporting evidence for the claim that Dutch disease effects may be weak or missing in fragile states is given by the degree of openness of fragile states, which is shown in the diagram below. As fragility increases, the size of exports as a share of GDP declines rapidly, suggesting that fragile states may not be able to support industries that are internationally competitive. This implies in turn that any impact of remittances on the tradables sector is greatly reduced relative to more 
stable states.

Figure 9: Openness and country fragility

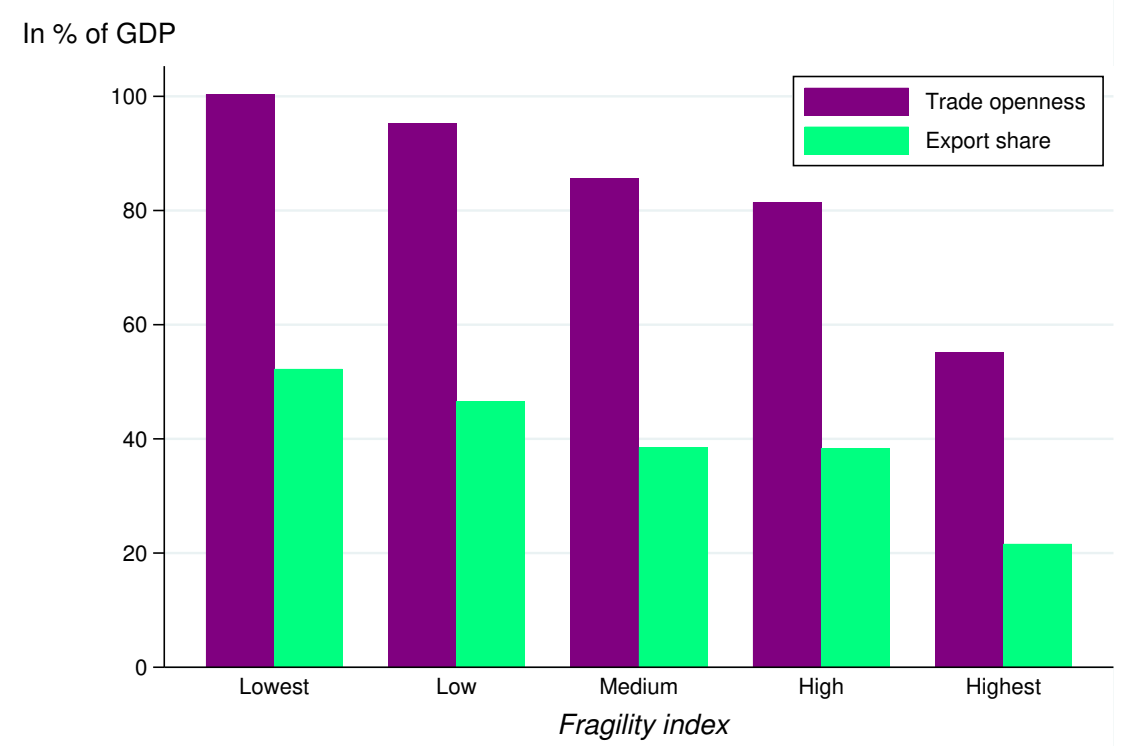

Note: Trade openness measured as the sum of exports and imports over GDP. The export share measures nominal export value over nominal GDP.

Source: IMF, World Economic Outlook Database.

Our findings mark an important difference in the impact of remittances on fragile states. In particular, they suggest that remittances are more clearly beneficial to the economies of fragile states than to more stable states because of the positive impact of remittances on wage growth. At the same time, however, research suggests that remittances may play a role in perpetuating the weak institutions that characterize fragile states (see, e.g., Abdih et al., 2012).

\section{Conclusion}

In this paper, we use cross-country, aggregate data to estimate several labor-market effects of remittances on recipient countries. Our approach differs from most of the existing literature, which typically examines one or two labor-market effects of remittances on a single country, using household survey data. One advantage of our approach is that it yields stylized facts that guide us toward a consistent narrative of how remittances affect recipient countries' labor markets.

The stylized facts that emerge from our study include the following. Remittances appear to have strong impacts on both labor supply and labor demand in recipient countries. On the supply side, remittances reduce labor force participation and increase informality of the labor market. On the demand side, remittances reduce 
overall unemployment. The size and significance of these effects, moreover, is greater than those of FDI and ODA on the same outcomes. This suggests that remittances may have greater effects on other labor market outcomes as well.

Our findings also suggest that the narrative explaining how remittances affect labor markets is fairly complex. We show that although remittances are associated with a decline in unemployment rates, they are also associated with lower wage growth and higher labor share of income, which implies lower productivity growth. Yet remittances also lower measured income inequality. We can tell a consistent story explaining these findings by appealing to the Dutch disease narrative, in which remittances benefit lower-wage, lower-productivity nontradables industries at the expense of the high-productivity, high-wage tradables industries. The results we obtain using sectoral estimations of employment tend to support this interpretation, as manufacturing employment is negatively related to remittances but construction, real estate, and transportation are positively related.

An additional indication of the complexity of the pathways through which remittances affect labor markets is found in the cross-country variation in the impacts of remittances that we document in this paper. We find substantial regional variation in remittances' effects on labor force participation, informality, and wage growth. In addition, we find distinctive differences in the effect of remittances on fragile states relative to more stable states. Our findings suggest that remittances affect fragile states differently than more stable states, such as the positive impact that remittances have on wage growth, but in the less-productive sector. With mounting evidence that remittances are also suspected of reducing the quality of institutions in recipient countries, and given the positive relation between governance and growth, this raises the possibility of whether remittances help stabilize incomes in fragile states at the expense of lower economic growth, a proposition that merits further research.

Further research is also needed to verify the stylized facts we present in our paper, as well as to discover other stylized facts that can help shed light on the labor market effects of remittances. In addition, testing the implications of our interpretation of the aggregate data is another task for future research. For example, our interpretation of the stylized facts implies that remittances lead to disproportionately large increases in employment in the nontradables sector, or in the less-productive or lower-skill segments of the labor market.

In addition, given the importance of labor markets to economic, financial and political stability, our research emphasizes the need for additional research that can inform the creation of comprehensive development strategies that take remittances into account. For example, research is needed to quantify the price distortions and negative externalities that remittances impose on formal labor markets and the tradables sector. Research is also needed to determine which policy approaches are likely to be most effective at mitigating the negative impacts of remittances. For example, investments in infrastructure, reforms to improve the ease of doing business, and 
changes in tax policy are policies that should be investigated further. Because remittances may impair the tradables sector, which is often perceived as an engine of development, researchers and policymakers need to push even harder to find development policies that improve competition and reduce informality. 


\section{References}

Abdih, Y. et al. 2012. "Remittances and institutions: Are remittances a curse?", in World Development, vol. 40, no. 4, pp. 657-666.

Abdulloev, I.; Gang, I.N.; Yun, M.S. 2014. "Migration, education, and the gender gap in labour force participation", in European Journal of Development Research, vol. 26 , pp. 509-526.

Acosta, P. 2011. "School attendance, child labour, and remittances from international migration in El Salvador", in Journal of Development Studies, vol. 47, no. 6, pp. 913-936.

Acosta, P.; Fajnzylber, P.; Lopez, J.H. 2008. "Remittances and household behavior: Evidence for Latin America", in Remittances and development: Lessons from Latin America (eds. P. Fajnzylber; J.H. Lopez) (World Bank).

Acosta, P.; Lartey, E.; Mandelman, F. 2009. "Remittances and the Dutch disease", in Journal of International Economics, vol. 79, no. 1, pp. 102-116.

Airola, J. 2008. "Labor supply in response to remittance income: The case of Mexico", in Journal of Developing Areas, vol. 41, pp. 69-78.

Alcaraz, C.; Chiquiar, D.; Salcedo, A. 2012. "Remittances, schooling, and child labor in Mexico", in Journal of Development Economics, vol. 97, no. 1, pp. 156-165.

Al Mamun, M. et al. 2015. "Remittance and domestic labor productivity: Evidence from remittance recipient countries", in Economic Modelling, vol. 47, pp. 207-218.

Amuedo-Dorantes, C.; Pozo, S. 2006a. "Migration, remittances and male and female employment patterns", in American Economic Review Papers and Proceedings, vol. 96, no. 2, pp. 222-226.

- 2006b. "Remittance receipt and business ownership in the Dominican Republic", in The World Economy, vol. 29, no. 7, pp. 939-956.

Antman, F.M. 2013. "The impact of migration on family left behind", in International handbook on the economics of migration (eds. A. Constant; K.F. Zimmermann) (Cheltenham, Edward Elgar Pub. Ltd.), pp. 293-308.

Ball, L.; Leigh, D.; Loungani, P. 2013. Okun's Law: Fit at fifty?, Working Paper 18668 (Cambridge, MA., National Bureau of Economic Research).

Barajas, A. et al. 2011. "Workers' remittances and the real exchange rate: Theory and evidence", in Economia, vol. 11, pp. 45-94.

Binzel, C.; Assaad, R. 2011. "Egyptian men working abroad: Labour supply responses by the women left behind", in Labour Economics, vol. 18, pp. 98-114. 
Burniaux, J.M.; Duval, R.; Jaumotte, F. 2003. Coping with ageing: A dynamic approach to quantify the impact of alternative policy options on future labour supply in OECD countries, Working Paper 371 (Paris, OECD).

Cabegin, E. 2006. The effect of Filipino overseas migration on the non-migrant spouse's market participation and labor supply behavior, IZA Discussion Paper 2240 (Bonn, Institute for the Study of Labor).

Calero, C.; Bedi, A.S.; Sparrow, R. 2009. "Remittances, liquidity constraints and human capital investments in Ecuador", in World Development, vol. 37, no. 6, pp. $1143-1154$.

Cazes, S.; Verick, S.; Al Hussami, F. 2013. "Why did unemployment respond so differently to the global financial crisis across countries? Insights from Okun's Law", in IZA Journal of Labor Policy, vol. 2, no. 1, pp. 1-18.

Chami, R.; Fullenkamp, C.; Jahjah, S. 2003. Are immigrant remittance flows a source of capital for development?, Working Paper 03/189 (Washington, DC., International Monetary Fund (IMF)).

Chami, R. et al. 2008. Macroeconomic consequences of remittances, IMF Occasional Paper 259 (Washington, DC., International Monetary Fund).

Damon, A.L. 2010. "Agricultural land use and asset accumulation in migrant households: The case of El Salvador", in Journal of Development Studies, vol. 46, pp. 162-189.

Demirgüç-Kunt, A.; Clapper, L.F.; Panos, G.A. 2011. "Entrepreneurship in postconflict transition: The role of informality and access to finance", in Economics of Transition, vol. 19 .

Docquier, F.; Ozden, c.; Peri, G. 2013. "The labour market effects of immigration and emigration in OECD countries", in The Economic Journal, vol. 124, pp. 1126-1145.

Drinkwater, S.; Levine, P.; Lotti, E. 2009. "Labor market and investment effects of remittances", in Development macroeconomics: Essays in memory of Anita Ghatak (eds. S. Ghatak; R. Levine) (Abingdon, Routledge), pp. 229-251.

Dustmann, C.; Frattini, T.; Rosso, A. 2015. "The effect of emigration from Poland on Polish wages", in Scandinavian Journal of Economics, vol. 117, pp. 522-564.

Edwards, A.C.; Rodríguez-Oreggia, E. 2009. "Remittances and labor force participation in Mexico: An analysis using propensity score matching", in World Development, vol. 37, no. 5, pp. 1004-1014.

Edwards, A.C.; Ureta, M. 2003. "International migration, remittances, and schooling: Evidence from El Salvador", in Journal of Development Economics, vol. 72, no. 2, pp. 429-461. 
Elsner, B. 2013a. "Does emigration benefit the stayers? Evidence from EU enlargement", in Journal of Population Economics, vol. 26, pp. 531-553.

- 2013b. "Emigration and wages: The EU enlargement experiment", in Journal of International Economics, vol. 91, pp. 154-163.

Ernst, E.; Rani, U. 2011. "Understanding unemployment flows", in Oxford Review of Economic Policy, vol. 27, no. 2, pp. 268-294.

Ernst, E. et al. 2016. Predicting wages around the globe, Working Paper (Geneva, International Labour Organisation).

Funkhouser, E. 1992. "Migration from Nicaragua: Some recent evidence", in World Development, vol. 20, pp. 1209-1219.

Grigorian, D.A.; Melkonyan, T.A. 2011. "Destined to receive: The impact of remittances on household decisions in Armenia", in Review of Development Economics, vol. 15 , pp. $139-153$.

Görlich, D.; Mahmoud, T.; Trebesch, C. 2007. Explaining labour market inactivity in migrant-sending families: Housework, hammock, or higher education, Kiel Working Paper 1391 (Kiel, Kiel Institute for the World Economy).

Hanson, G. 2007. Emigration, remittances and labor force participation in Mexico, Inter-American Development Bank Working Paper 28 (Washington, DC, InterAmerican Development Bank).

ILO. 2010. Trends econometric models: A review of the methodology (Geneva, International Labour Organization).

-. 2015. Key Indicators of the Labour Market (KILM) (Geneva, ILO).

ILO; WTO. 2009. Globalization and informal employment (ILO, WTO).

Ivlevs, A. 2016. Remittances and informal work, Discussion Paper 10196 (Bonn, IZA).

Jackmann, M. 2014. "A note on the labor market effects of remittances in Latin American and Caribbean Countries: Do thresholds exist?", in The Developing Economies, vol. 52, no. 1, pp. 52-67.

Khanal, U. et al. 2015. "Implications of out-migration in rural agriculture: A case study of Manapang village, Tanahun, Nepal", in The Journal of Developing Areas, vol. 49, pp. 331-352.

Kim, N. 2007. The impact of remittances on labor supply: The case of Jamaica, World Bank Policy Research Working Paper 4120 (Washington, DC., World Bank). 
Kozel, V.; Alderman, H. 1990. "Factors determining work participation and labour supply decisions in Pakistan's urban areas", in Pakistan Development Review, vol. 29, no. 1, pp. 1-18.

Lokshin, M.; Glinskaya, E. 2009. "The effect of male migration on employment patterns of women in Nepal", in World Bank Economic Review, vol. 23, no. 3, pp. $481-507$.

Mishra, P. 2014. "Emigration and wages in source countries: A survey of the empirical literature", in International Handbook on Migration and Economic Development (ed. R.E.B. Lucas) (Cheltenham, Edward Elgar Pub. Ltd.), pp. 241-266.

Posso, A. 2012. "Remittances and aggregate labor supply: Evidence from sixty-six developing nations", in The Developing Economies, vol. 50, no. 1, pp. 25-39.

Rodriguez, E.R.; Tiongson, E.R. 2001. "Temporary migration oversears and household labor supply: Evidence from urban Philippines", in International Migration Review, vol. 35, no. 3, pp. 709-725.

Solt, F. 2016. "The standardized world income inequality database", in Social Science Quarterly, vol. 97.

Stanley, D. 2015. "Can international transfers be probproblem? Honduran remittances and labor supply decisions", in Contemporary Economic Policy, vol. 33, pp. $550-570$.

Yang, D. 2008. "International migration, remittances and household investment: Evidence from Philippine migrants' exchange rate shocks", in The Economic Journal, vol. 118, pp. 591-630. 


\section{$5 \quad$ Appendix}

\subsection{Summary statistics}

Table 9: Summary statistics

\begin{tabular}{|c|c|c|c|c|c|}
\hline Variable & \#Observations & Mean & Std. Dev. & Min & Max \\
\hline Working-age population (in \%) & 3,799 & 69.1 & 11.6 & 43.0 & 100.0 \\
\hline Labor force participation rate (in \%) & 4,080 & 63.3 & 10.4 & 39.9 & 90.2 \\
\hline Unemployment rate (in \%) & 4,080 & 9.3 & 6.8 & 0.1 & 40.2 \\
\hline Real wage growth (p.a., in \%) & 2,315 & 2.3 & 6.1 & -30.6 & 47.0 \\
\hline Share of informal employment (in \%) & 4,080 & 40.8 & 28.1 & 0.3 & 96.0 \\
\hline \multicolumn{6}{|c|}{ Employment shares (in \% of total employment) } \\
\hline ...Agriculture & 4,080 & 30.2 & 24.9 & 0.2 & 90.9 \\
\hline ...Manufacturing & 4,080 & 13.1 & 7.5 & 0.2 & 43.0 \\
\hline ...Construction & 4,080 & 6.3 & 4.2 & 0.1 & 46.7 \\
\hline ...Accommodation and restaurants & 4,080 & 3.2 & 2.6 & 0.1 & 20.3 \\
\hline ...Health and social work & 4,080 & 4.6 & 3.9 & 0.1 & 21.6 \\
\hline Market GINI & 2,825 & 45.0 & 7.6 & 18.0 & 72.8 \\
\hline Remittances (in \% of GDP) & 2,343 & 3.3 & 5.4 & 0.0 & 49.4 \\
\hline FDI (in $\%$ of GDP) & 3,227 & 5.6 & 30.7 & -46.2 & 726.8 \\
\hline Official development aid (in \% of GDP) & 2,976 & 6.0 & 8.7 & -0.7 & 115.4 \\
\hline Real GDP growth (p.a., in \%) & 4,080 & 3.8 & 6.4 & -52.6 & 147.7 \\
\hline Investment share (in \% of GDP) & 3,602 & 23.0 & 11.0 & 0.1 & 227.5 \\
\hline Trade openness (in \% of GDP) & 3,725 & 84.2 & 52.9 & 4.9 & 809.2 \\
\hline real GDP per capita (in Int\$ PPP) & 3,736 & 9158.8 & 14457.9 & 30.9 & 112429.4 \\
\hline
\end{tabular}




\subsection{Regional country coverage}

Table 10: Regional country coverage

\begin{tabular}{|c|c|}
\hline Region & Countries \\
\hline Central and Western Asia & $\begin{array}{l}\text { Armenia, Azerbaijan, Cyprus, Georgia, Israel, Kaza- } \\
\text { khstan, Kyrgyzstan, Tajikistan, Turkey, Turkmenistan, } \\
\text { Uzbekistan }\end{array}$ \\
\hline Eastern Asia & $\begin{array}{l}\text { China, Hong Kong SAR, Japan, South Korea, Mongolia, } \\
\text { Taiwan POC }\end{array}$ \\
\hline Eastern Europe & $\begin{array}{l}\text { Belarus, Bulgaria, Czech Republic, Hungary, Moldova, } \\
\text { Poland, Romania, Russian Federation, Slovakia, } \\
\text { Ukraine }\end{array}$ \\
\hline Latin America and & Argentina, Bahamas, Barbados, Belize, Bolivia, Brazil, \\
\hline Caribbean & $\begin{array}{l}\text { Chile, Colombia, Costa Rica, Dominican Republic, } \\
\text { Ecuador, El Salvador, Guatemala, Guyana, Haiti, Hon- } \\
\text { duras, Jamaica, Mexico, Nicaragua, Panama, Paraguay, } \\
\text { Peru, Suriname, Trinidad and Tobago, Uruguay, } \\
\text { Venezuela }\end{array}$ \\
\hline Middle East & $\begin{array}{l}\text { Bahrain, Iraq, Jordan, Kuwait, Lebanon, Oman, Qatar, } \\
\text { Saudi Arabia, Syrian Arab Republic, United Arab Emi- } \\
\text { rates, Yemen }\end{array}$ \\
\hline Northern Africa & Algeria, Egypt, Libya, Morocco, Sudan, Tunisia \\
\hline Northern America & Canada, United States \\
\hline $\begin{array}{l}\text { Northern, Southern and } \\
\text { Western Europe }\end{array}$ & $\begin{array}{l}\text { Albania, Austria, Belgium, Bosnia and Herzegovina, } \\
\text { Croatia, Denmark, Estonia, Finland, France, Germany, } \\
\text { Greece, Iceland, Ireland, Italy, Latvia, Lithuania, Lux- } \\
\text { embourg, Macedonia, Malta, Montenegro, Netherlands, } \\
\text { Norway, Portugal, Serbia, Slovenia, Spain, Sweden, } \\
\text { Switzerland, United Kingdom }\end{array}$ \\
\hline $\begin{array}{l}\text { South-Eastern Asia and the } \\
\text { Pacific }\end{array}$ & $\begin{array}{l}\text { Australia, Brunei Darussalam, Cambodia, Fiji, Indone- } \\
\text { sia, Lao PDR, Malaysia, Myanmar, New Zealand, Papua } \\
\text { New Guinea, Philippines, Singapore, Solomon Islands, } \\
\text { Thailand, Timor-Leste, Vietnam }\end{array}$ \\
\hline Southern Asia & $\begin{array}{l}\text { Afghanistan, Bangladesh, Bhutan, India, Iran, Mal- } \\
\text { dives, Nepal, Pakistan, Sri Lanka }\end{array}$ \\
\hline Sub-Saharan Africa & $\begin{array}{l}\text { Angola, Benin, Botswana, Burkina Faso, Burundi, } \\
\text { Cameroon, Cape Verde, Central African Republic, } \\
\text { Chad, Comoros, Congo, Democratic Republic of the } \\
\text { Congo, Cote d'Ivoire, Equatorial Guinea, Eritrea, } \\
\text { Ethiopia, Gabon, Gambia, Ghana, Guinea, Guinea- } \\
\text { Bissau, Kenya, Lesotho, Liberia, Madagascar, Malawi, } \\
\text { Mali, Mauritania, Mauritius, Mozambique, Namibia, } \\
\text { Niger, Nigeria, Rwanda, Senegal, Sierra Leone, Soma- } \\
\text { lia, South Africa, Swaziland, Tanzania, Togo, Uganda, } \\
\text { Zambia, Zimbabwe }\end{array}$ \\
\hline
\end{tabular}

